*ak RMIS View/Frint Document Cover Sheet tow

This document was retrieved from the Documentation and Records Manaqement (DRM) ISEARCH System. It is intended for Information only and may not be the most recent or updated version. Contact a Document Service Center (see Hanford Info for locations) if you need additional retrieval information.

Accession \#: D196027043

Document \#: SD-WM-ATR-105

Title/Desc:

DIESEL GENERATOR ACCEPTANCE TEST REPORT

Pages: 47 


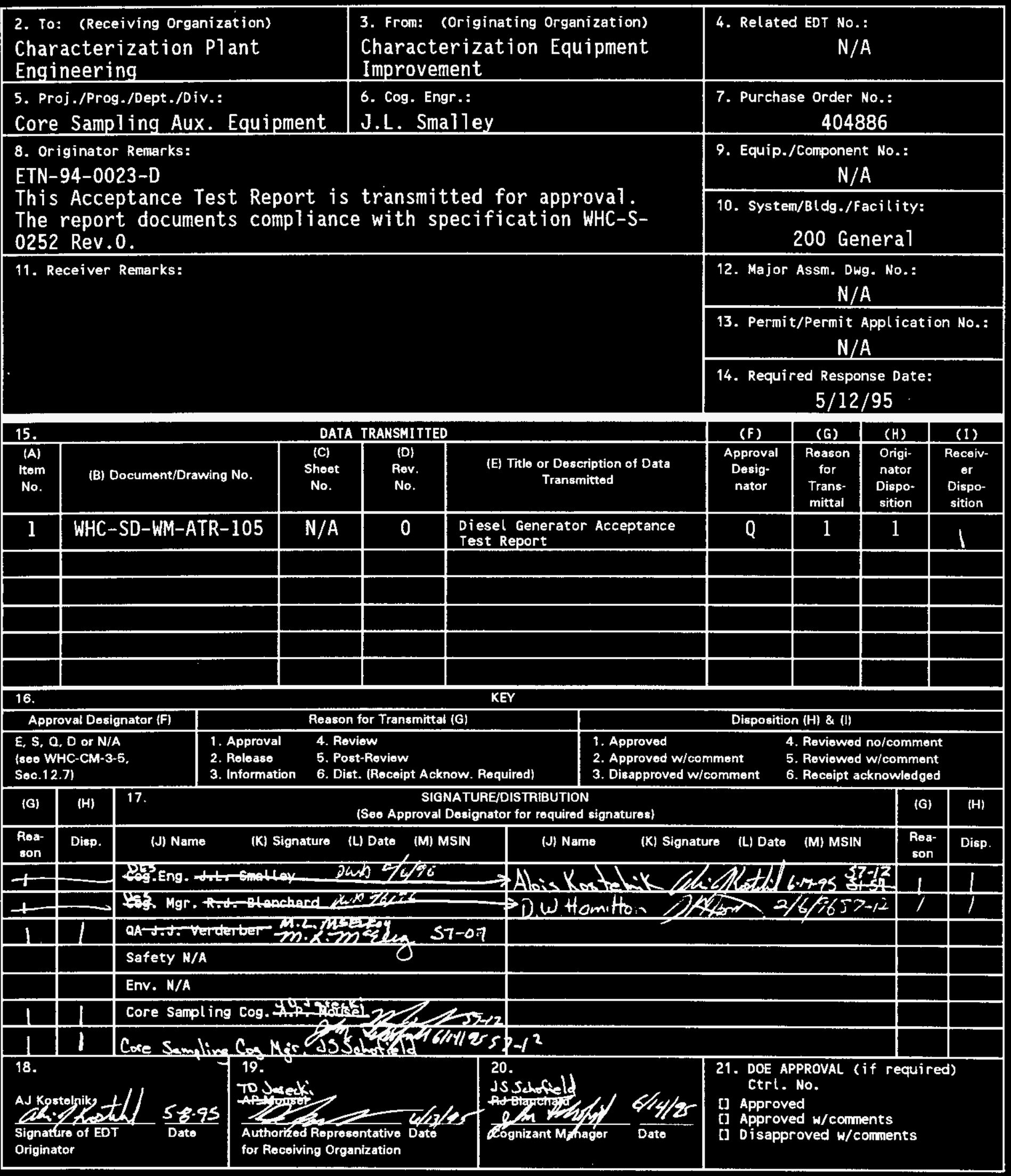

BD-7400-172-2 (04/94) GEF097 


\title{
DIESEL GENERATOR ACCEPTANCE TEST REPORT
}

\author{
ALOIS J. KOSTELNIK \\ WESTINGHOUSE HANFORD COMPANY, Richland, WA 99352 \\ U.S. Department of Energy Contract DE-AC06-87RL10930
}

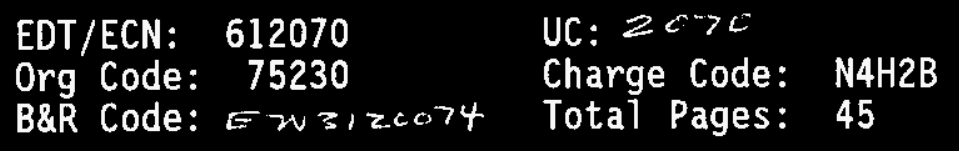

Key Words: ETN-94-0023-D, Core Sampling, Diesel Generator, Specification WHC-S-0252, Cummins, Onan, 150KW Generator, Purchase Order 404866, Core Sampling Ancillary Equipment

Abstract: This Acceptance Test Report documents compliance with the requirements of specification WHC-S-0252. The equipment was tested according to WHC-SD-WM-ATP-105 Rev.0.

TRADEMARK DISCLAIMER. Reference herein to any specific commercial product, process, or service by trade name, trademark, manufacturer, or otherwise, does not necessarily constitute or imply its endorsenent, recommendation, or favoring by the United States Government or any agency thereof or its contractors or subcontractors.

Printed in the United states of America. To obtain copies of this document, contact: WHC/BCS Document Control Services, P.0. Box 1970, Mailstop 46-08, Richland WA 99352, Phone (509) 372-2420; Fax (509) 376-4989.
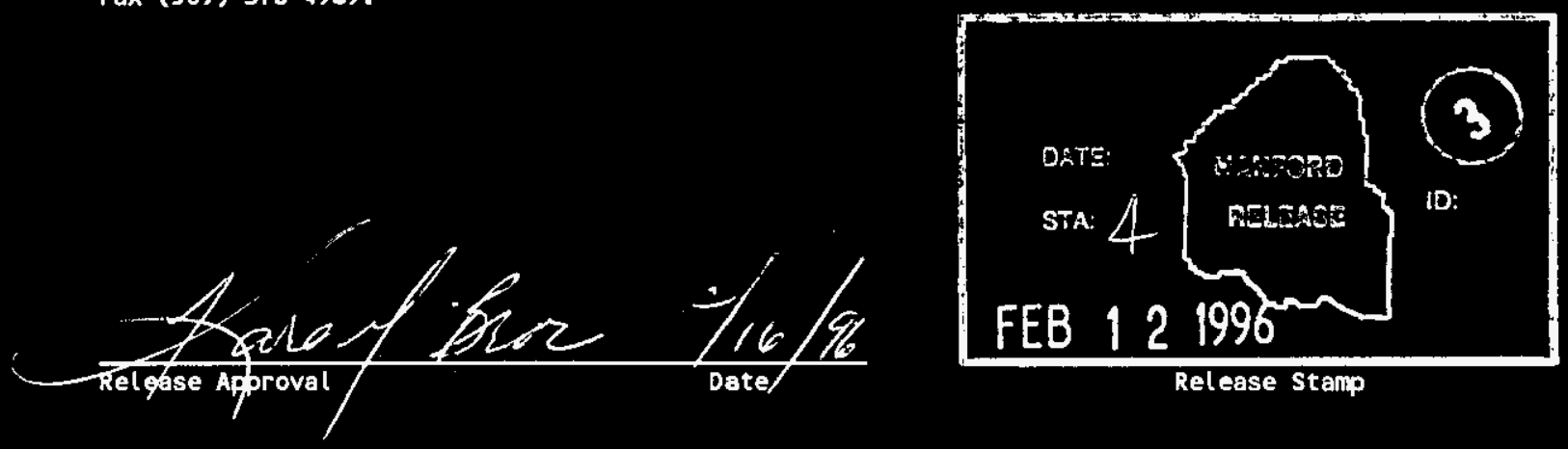

Approved for Public Release 
WHC-SD-WW-ATR-105

REV.0

Page 2

\section{TABLE OF CONTENTS}

SUMMARY

APPENDIX A (ATP results for Genset SN E940542240)

APPENDIX B (ATP results for Genset SN F940547197)

APPENDIX C (NEC Inspection Results)

APPENDIX D (Receipt Inspection Report)
Page 3

Page Al

Page B1

Page C1

Page D1 


\section{SUMMARY}

The test was performed at Cummins Northwest's facility in Renton, WA. A11 steps and exceptions were completed at the time of testing. The NEC Inspection discovered items that needed repair which were verified upon receipt inspection.

One item which was not written as an exception is the 88 decibel noise recording for the generator sets. The Gensets were parked on an asphalt drive, next to a shop area for access to fuel, tools and test equipment during the test. The control station for the generator was between the generator and the shop wall1. If the noise meter was moved to either side of the control panel the noise level dropped indicating that the cinder block shop wall was reflecting the noise back at the Genset and influencing the noise measurement. After considering the test conditions and the fact that the Gensets will be used in the field, parked on sand, the 88 decibel noise level was judged as acceptable without retesting.

The attached Appendix A contains the Acceptance Test Results for Genset Model \# 150DGFA, Serial \# E940542240. Appendix B contains the Acceptance Test Results for Genset Model \# 150DGFA, Serial \# F940547197. Appendix C contains the Internal Memo from Electrical Power Systems Engineering which includes the NEC Inspection results for both Gensets. Appendix D includes the Receipt Inspection Report for both Gensets. 
WHC-SD-WM-ATR-105

Rev. 0

Appendix A-1 of A-19

1 of -1

608068

2. To: (Receiving Organization) Core Sampling

5. Proj./Prog./Dept./Div.: Core Sampling Aux. Equipment

3. From: (originating Organization) Characterization Equipment

6. Cog. Engr.:

J.L. Smalley

8. Originator Renarks:

ETN-94-0023-D

This Acceptance Test Procedure is transmitted for approval. performed at the Sellers location. It will show compliance with specification WHC-S-0252 Rev t.1 a $k$ 4-7-4y

11. Receiver Remarks: The procedure was prepared by the Seller and will be

4. Related EDT MO.:

$N / A$

7. Purchase Order Mo.: 404886

9. Equip./Component No.:

$N / A$

10. Systen/8tdg./Facility:

\section{General}

12. Major Assm. Oug. No.: $N / A$

13. Permit/Permit Application No.: $N / A$

14. Required Response Date: $9 / 15 / 94$

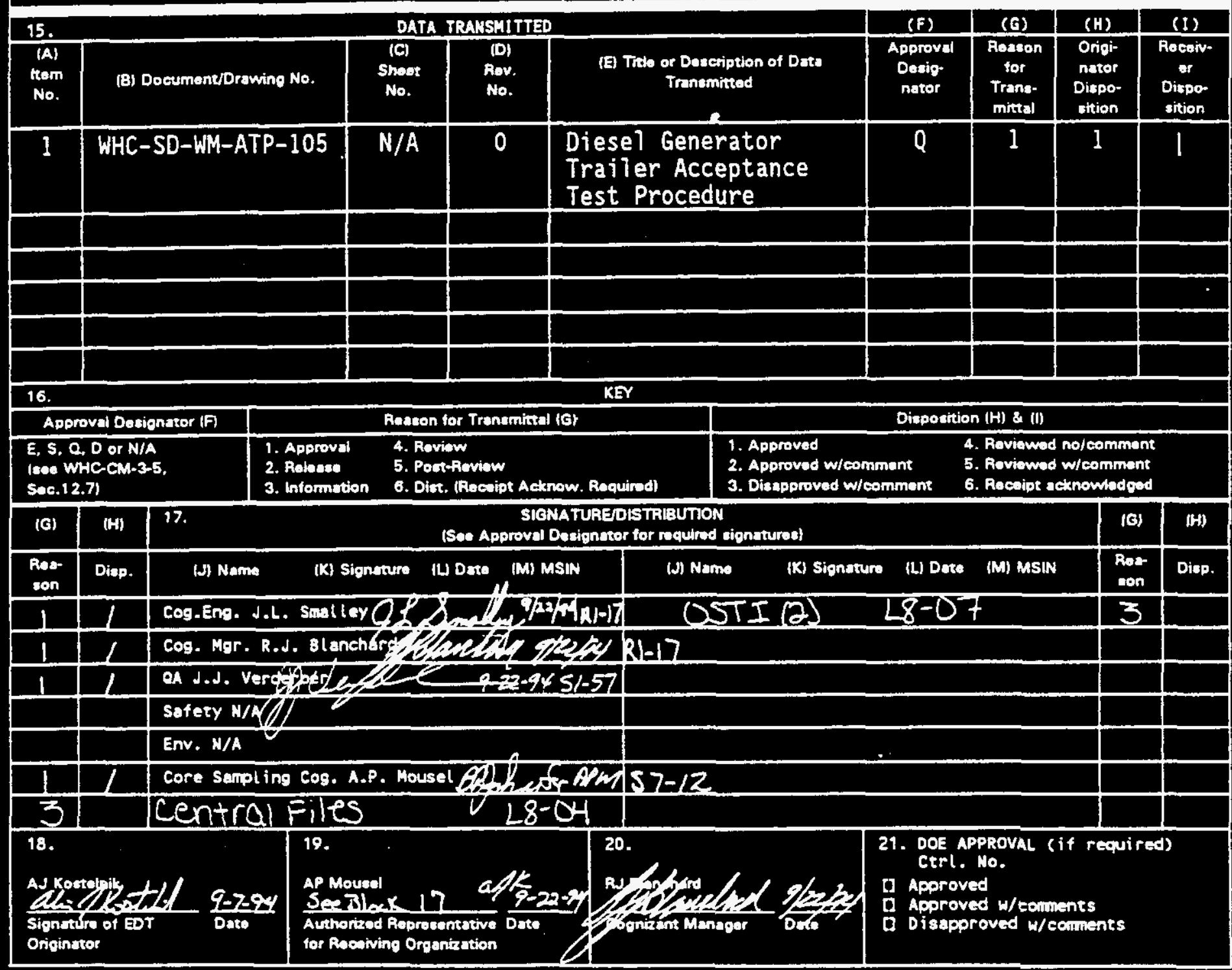




\section{RELEASE AUTHORIZATION}

Document Number: WHC-SD-WM-ATP-105, REV 0

Document Title: $\quad$ Diesel Generator Trailer Acceptance Test Procedure

Release Date: $\quad 9 / 23 / 94$

This document was reviewed following the procedures described in WHC-CM-3-4 and is:

APPROVED FOR PUBLIC RELEASE

WHC Information Release Administration Specialist:

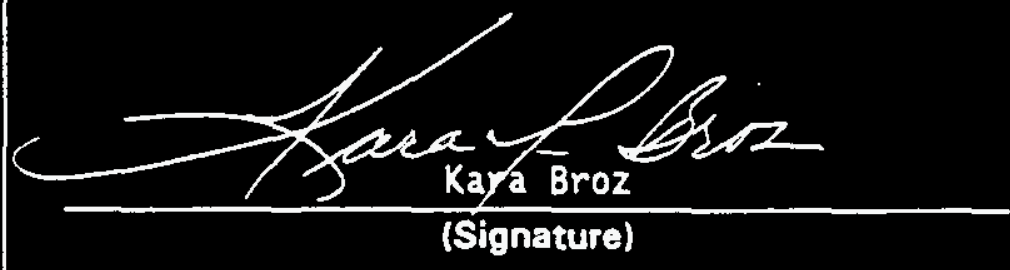

$\frac{9 / 23 / 94}{\text { (Date) }}$


2. Titte

Diesel Generator Trailer Acceptance Test Procedure

3. Nuiber

5. Key Words

ETN-94-0023-D

Core Sampling, Diesel Generator, Specification

WHC-S-0252, Trailer, Cummins, Onan, 150KW

Generator, Purchase Order 404886 , Core Samp Ting

Auxil iary Equipment

zlmén Slas APPROVED FOF PUBLIC RELEASE

7. Abstract

WHC-SD-WM-ATP-105

4. Kev nо.

6. Author

Nane: Alois $\mathbf{J}$ Kostelnik

Signature

Organization/Charge code 7EA40/

This Acceptance Test Procedure (ATP) will document compliance with the requirements of WHC-S-0252 Rev.1 and ECNs 609271, and 609272. The equipment being tested is a 150KW Diesel Generator mounted on a trailer with switchgear. The unit was purchased as a Design and Fabrication procurement activity. The ATP was written by the Seller and will be performed by the Seller with representatives of the Westinghouse Hanford Company witnessing the test at the Seller's location.

8. PUnaose AND USE of DOCunENT - This docunent was prepared for use with in the U.S. Deportment of Energy and its contractges? It is to be used onte to perform, direct, or inteneere work under U.S. Department of Energy contracts. This doodient is not approved for publ ic release until revieved.

PATENT status - This docunanpop, since it is transmitted in advance of patent clearaper, is made available in confidence solely for use in perfomence of work wook contracts with the U.S. Department of Energy. This document is noter be publ ished nor its conteat otherwise disseminated or used for purposes other than specifted above before patent aporoval for such release omuse has been secured, upon request, from the Patent Counsel, U.S. Department of Energy Field office, $R$ ichtand, wh.

10.

RELEASE STAMP

DISCLAINER - This report was prepared as an account of work sponsored by an agency of the United States Goverment. Neither the United States Govermment nor any agency thereof, nor any of their enployees, nor any of their contractors, subcontractors or their ellployees, makes any warranty, express or inpl ied, or assumes any legal liability or responsibility for the accuracy, eampleteness, or any third party's use or the results of such use of any information, apparatus, product, or process disclosed, or represents that its use would not infringe privately ounce rights. Reference herein to any specific catmercial product, process, or service by trade nane, trademark, manufacturer, or otherwise, does not necessarity constitute or inply its endorsement, recombendation, or favoring by the United States Govermint or any agency thereof or its contractors or subcontractors. The views and opinions of authors expressed herein do not necessarily state or reflect those of the United States Government or any agency thereof.

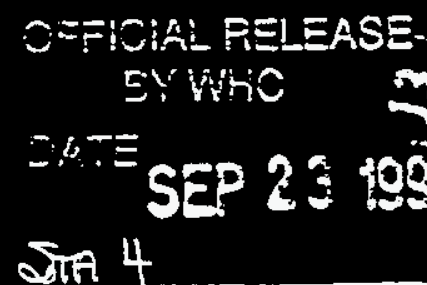

9. Impact level $Q$ 
WHC-SD-WM-ATR-105

Rev. 0

Appendix A-4 of A-19

\section{TABLE OF CONTENTS}

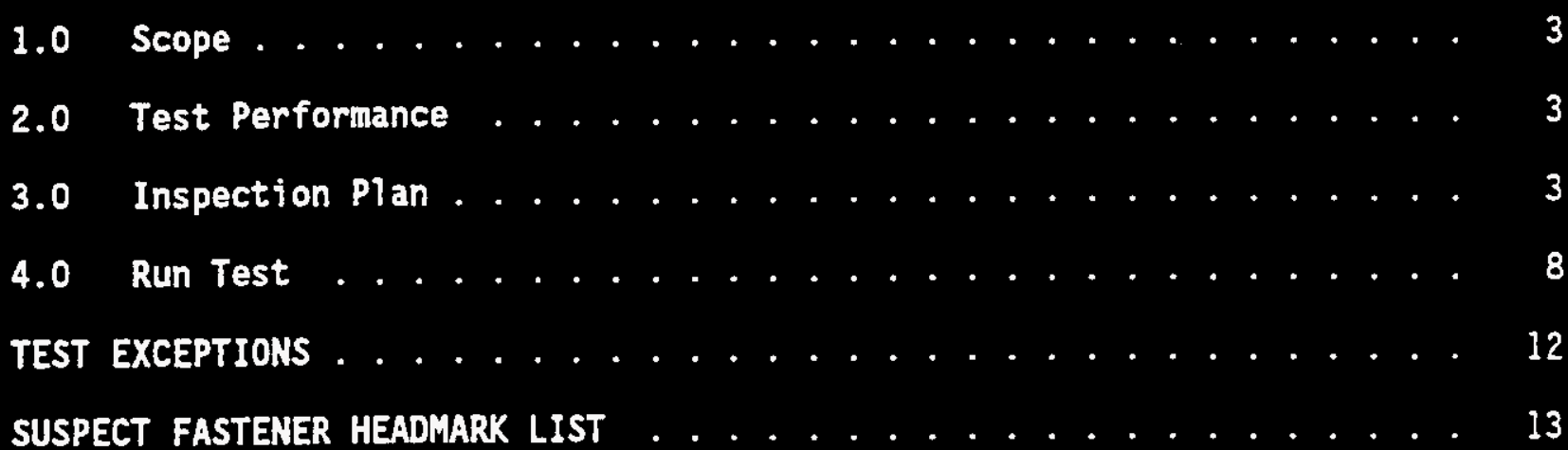




\subsection{Scope}

This acceptance test procedure is to verify that the trailer mounted $150 \mathrm{KW}$ Cummins/Onan Diesel Generator Set meets the requirements of West inghouse Hanford specification WHC-S-0252.

\subsection{Test Performance}

Cummins Northwest will complete the following test in the order deemed best by Cummins personnel. Westinghouse Hanford Company (WHC) personnel shall witness all testing and shall perform the inspection portion of the test. All steps will be completed and any exceptions shall be noted on the attached exception sheet along with the resolution. Cummins Northwest shall resolve all exceptions with the concurrence of WHC.

\subsection{Inspection Plan}

3.1 Record the model and serial numbers of the Generator Set and Trailer.

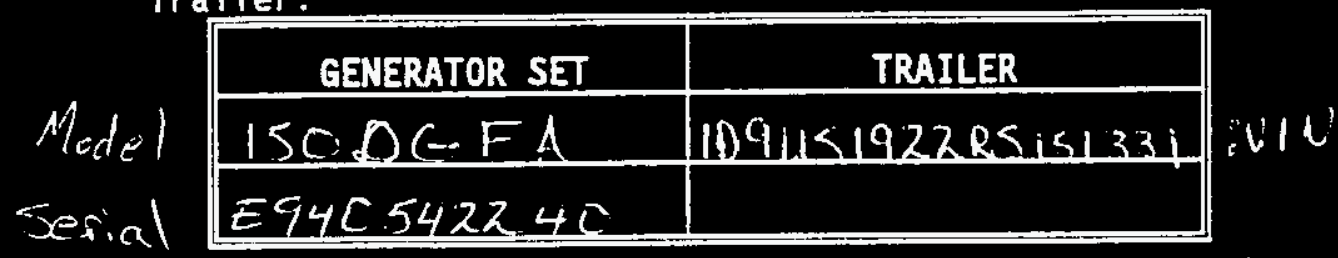

3.2 Verify by record review that the generator is capable of the following:

(j) 3.2.1 3-phase, 4-wire, 277/480 VAC and single-phase 240/120 VAC.

(L) 3.2.2 Operating frequency is 60 Hertz $\pm 0.5 \%$.

Cif 3.2.3 Standby Rating Range is 150KW 0.8 power factor.

c 3.2 .4 Prime Rating Range is $135 \mathrm{KW}$ e 0.8 power factor.

(i) 3.2 .5 Voltage dip does not exceed $20 \%$ of rated voltage upon

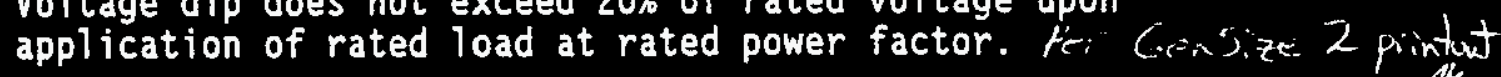

(1) 3.2 .6 voltage regulation under $10 \mathrm{od}$ from no 10 ad to $100 \% 10 \mathrm{ad}$ is within $\pm 2 \%$ of rated voltage, $( \pm 10 \mathrm{~V})$.

GSא 3.2.7 Frequency regulation under varying loads, from no load to $100 \%$ load is within $\pm 3 \mathrm{~Hz}$. 
3.3 Verify the control panel contains the following:

at)

3.3.1 Run-0ff-Auto switch: (Run: manually start engine) (Off: stop engine) (Auto: start engine by closing of a remote contact) Run-cff-Remote

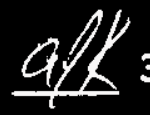

3.3.2 Accessible remote start-stop terminals.

3.4 Verify controls are provided to shutdown and lock out the engine under the following abnormal operating conditions:

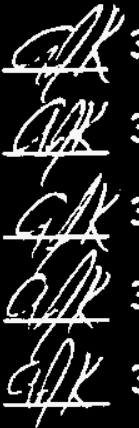

3.4.1 Engine failure to start after a specified cranking time.

3.4.2 Engine over-speed.

3.4.3 Engine low lube oil pressure.

3.4.4 Engine high operating temperature.

3.4.5 Remote manual stop activated.

3.5 Verify the following instrumentation is provided as a minimum:

(4)

3.5.1 Engine lube oil pressure gauge.

3.5.2 Coolant temperature gauge.

3.5.3 Hour meter.

the

3.5.4 Battery volt meter.

3.5.5 Fuel gauge for day tank.

$\frac{14 k}{1}$ 3.5.6 Cranking time meter (Internal timer, alarm light indicator) 3.4 .1 .
3.5.7 Other instruments normally provided by the manufacturer for
the proper operation and maintenance of their enginegenerator set. Pre High Ensine Temperature

3.6 Verify battery-powered visual and audible alarms for the following condition as a minimum are provided. Verify alarm test switch, lamp test switch and alarm reset switch and contacts for each a] arm for remote signaling are provided:

3.6.1 Over-crank shutdown.

3.6.2 High engine temperature shutdown.

3.6.3 Low engine lube oil pressure shutdown.

3.6.4 Over-speed of engine shutdown. 
3.7 Verify the generator AC power output monitoring and controls include the following as a minimum:

Le/

3.7.1 AC voltmeter with a phase selector switch with an OFF position.

Af)

3.7.2 AC anmeter with a phase selector switch with an OFF position.

12

3.7.3 Frequency meter.

3.7.4 AC voltage adjust rheostat.

3.7.5 Generator output circuit breaker with manual reset.

3.8 Verify the following equipment has been installed:

LAL

3.8.1 The basic trailer is/provided with an electrical equipment rack located on the-3ide- of the engine-generator set enclosure that does not increase the total width dimension of the unit. The equipment rack is located for easy access but allows accessibility to the engine-generator set for maintenance and operation. All receptacles are on the same side of the generator and labels are mechanically fastened to the equipment with screws.

3.8.2 The distribution and wiring system have been installed per NFPA 70, Nationa? Electrical Code. Sec- Excipt.1

3.8.3 There is a 25KVA transformer on the unit to provide single phase power of $240 / 120$ volt. The transformer has fault protection on the primary side.

3.8.4 A lookW load bank is on the unit. The load bank is divided into 3 sections, 2 (two) 25KW and 1 (one) 50KW sections, which may be manually switched on individually as required to maintain the generator near $70 \%$ of capacity. The load bank is wired for operation in parallel with the normal load. 
3.8.5 The electrical equipment furnished by the engine-generator set Supplier, mounted on the equipment rack outside of the engine-generator set enclosure, and wired to the generator output terminals via a 3-phase, 4-wire bus is as follows: (Rated current capacity of components shall not be less than the rating requested.)

One (1), 3-pole, 3-wire, 150 amp rated, 80 amp trip, 600 VAC, lockable circuit breaker. A 100 amp. receptacle is on the load side of the circuit breaker and is 7 abeled as "SERVICE TRAILER 240 VAC 80 AMPS". The receptacle is an Appleton Cat. \# ADR1034.

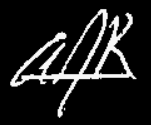

3.8 .5 .2

One (1), 3-pole, 3-wire, 150 amp rated, 50 amp trip, 600 YAC, time delay lockable circuit breaker. A 60 amp. receptacle is on load side of the circuit breaker and is labeled as "BREATHING AIR CONPRESSOR 480 VAC 50 AMPS". The receptacle is an Appleton Cat. \# ADR6034.

3.8.5.3 One (1), 3-pole, 3-wire, $200 \mathrm{amp}$ rated, $110 \mathrm{amp}$ trip, 600 VAC, iockable circuit breaker. A 200 amp. receptacle to the load side of the circuit breaker and label receptacle as "UTILITY 480 VAC 110 AMPS". The receptacle is an Appleton Cat. \#APR20044 ADR not avilable.

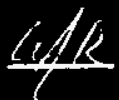

3.8 .5 .4

One (1), 20 amp, 240 VAC, single receptacle, wired from a two pole, 20 amp breaker to be used for hookup of temporary power boxes. Labeled as "240 VAC 20 AMPS".

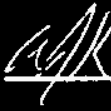

3.8 .5 .5

One (1), 20 amp, 120 VAC, duplex receptacle, wired from a single pole, 20 amp breaker with ground fault protection, to be used for hookup of temporary tools and lighting. Labeled as "120 VAC 20 AMPS".

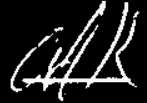

3.8 .5 .6

One (1), 30 amp, 120 VAC, single receptacle, wired from a single pole, 30 amp breaker. Labeled as "PURGE GAS TRAILER 120 VAC 30 AMPS".

3.8.6 The unit has grounding rods and a 100 foot cable to allow grounding to a ground grid.

$$
\begin{aligned}
& \text { Te be verified at receipt } \\
& \text { Inspecticin, cojk } \\
& =4 \text { Copper minimumerifk }
\end{aligned}
$$


3.9 Verify the following engine-generator trailer requirements are satisfied:

Q1) 3

3.9.1 The engine-generator set including all accessories are mounted on a heavy duty type trailer designed for use in construction, communications, and utility applications.

cifk

3.9.2 The trailer meets Department of Transportation (DOT) requirements for highway travel. (DOT Certification)

afk

3.9.3 Vibration isolators are used between the engine-generator set and the tratier.

les

3.9.4 The trailer is equipped with running lights, brake lights, safety brake, stabilizer jack on each corner; a front wheel jack with whee?; and hitches.

$\mathscr{M}$

3.9.5 The trailer has a $23 / 4$ inch Lunette hitch with vertical adjustment.

3.9.6 The underside of the trailer is undercoated for rust protection.

G) 3.9.7 The trailer has hydraulic surge type brakes. 3.9.8 The generator is within an enclosure and the enclosure is
lined with sound deadening material.

3.9.9 The instruments and controls are vibration isolated to prevent gauge and control malfunction. 
3.10 Verify the following engine requirements are satisfied:

(1)

3.10 .1

3.10 .2

3.10 .3

I/K 3.10 .4

I/K 3.10 .5

IR 3.10 .6

cels 3.10 .7

sk 3.10 .8

偆 3.10 .9

(I) 3.10 .10

YK 3.10 .11
Diesel fuel engine.

Engine shall be electric start from negative grounded battery supplied.

Battery shall be charged with alternator having automatic voltage regulation supplied with engine.

A fuel tank is on the unit that will supply fuel for the engine to operate at full load for at least 24 hours. (Capacity $25 \mathrm{C}$ gal, Consumption rate 9.2 gal $/ \mathrm{hr}$ )

Two (2) stage dry type air cleaner with a restriction gauge.

Furnished with the capability for cold weather starting such as electric glow plugs. Engine hot start 1500 watt, 110 volt heater.

Record the freeze point of the engine antifreeze. $\left(-4 l^{\circ} \mathrm{F}\right)$

Drip pan to catch fuel or oil leaks.

Painted inside and out. Exterior is White.

Verify there are no Suspect Fasteners as identified on the U.S. Custom's Fasteners Headmark List.

Verify all visible welds are acceptable per AWS DI.1.

4.0 Run Test

4.1 No Load Cold start: Verify that the engine starts and comes to $1800 \pm 9 \mathrm{rpm}$ in the specified time. (MFR $\left(-1 \mathrm{Csec}_{\mathrm{s}}\right.$ )

G/K 4.1.1 Switch Run-0ff-Auto switch to Run.

(Time from close of contacts to $1800 \mathrm{rpm} \& \mathrm{sec}$. )

4.1.2 Verify the following instrumentation is functional and the value indicated is within the range specified by the manufacturer:

C/K 4.1.2.1 Engine lube oil pressure gauge.

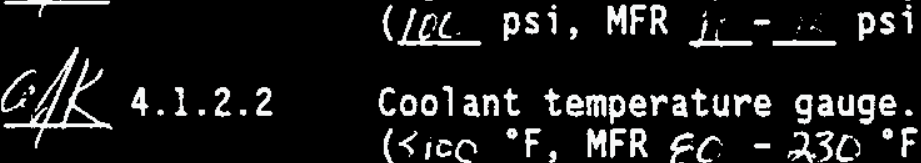


L.) $/ 4.1 .2 .3 \quad \begin{aligned} & \text { Hour meter. } \\ & (1.4 \text { hrs })\end{aligned}$

G.X 4.1.2.4 Batitery volt meter.

(26 volts, MFR $24-30$ volts)

C.X Fuel gauge for day tank.

(Empty level)

lif 4.1.2.6 Other instruments normally provided by the

manufacturer for the proper operation and maintenance of their particular engine-generator set.

4.1.3 Record and with a sound meter the generator noise level at the electrical control panel and verify that it is less than 85 decibels. \&E decibels. Lit of trapper mise it tost s.te\&/K

4.2 Loaded Cold start with Remote/Auto start: Verify, with the $100 \mathrm{KW}$ load bank on line, that the engine starts, comes to $1800 \pm 9 \mathrm{rpm}$, and the load is automatically switched on-line in the specified time. (MFR C - isec.)

4.2.1 Switch Run-0ff-Auto switch to Auto.

4.2.2 Close contacts on a temporarily installed switch.

(Time from close of contacts to load on-line. $2 \mathrm{sec}$. )

4.2.3 Switch Run-0ff-Auto switch to Off. (Remove temporary switch.)

4.3 Verify controls shutdown and lock out the engine under the following simulated abnormal operating conditions. (Temporarily install contacts and jumpers as required to simulate conditions. Restart the generator between each alarm test.) Verify alaril test switch, lamp test switch and alarm reset switch are operationa]:

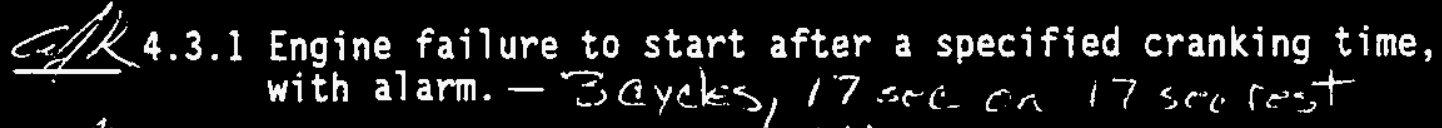

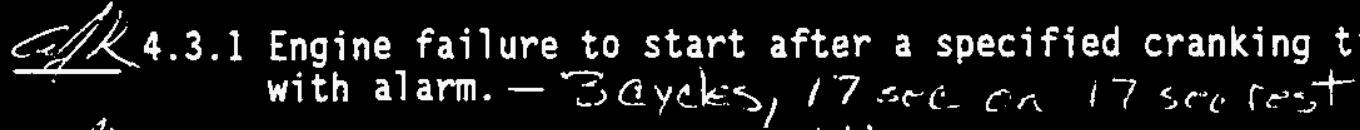

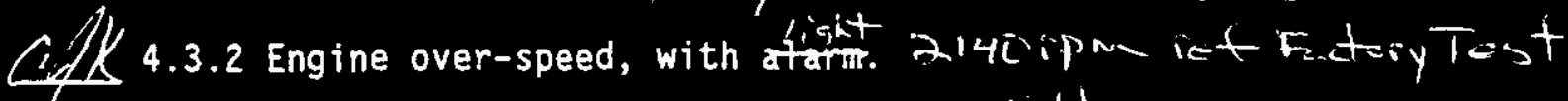

an 4.3.3 Engine low lube oil pressure, with afarm.

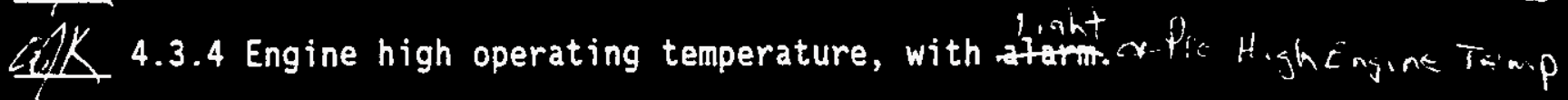

CilK 4.3.5 Remote manual stop activated. (toeated on distributionpanelf- Temporary Suiteh 
4.4 Verify proper operation of the generator, power distribution components and load bank according to the manufacturer's supplied information. (For load bank test operate for 15 minutes at each step prior to recording information.)

4.4.1 Step 1 (25KW Resistive Load for $15 \mathrm{~min}$. )

L.) 4.4.1.1 Amperage 130,230, 330 amps

AL 4.4.1.2 Voltage 1-2 $48.3,2-3484,1-34 E 3$

द्र 4.4.1.3 Frequency $62.1 \mathrm{~Hz}$

Ifl 4.4.1.4 011 Pressure EO psi

4.4.1.5 Water Temperature $125^{\circ} \mathrm{F}$

4.4.2 Step 2 Y50KW Resistive Load for 15 min.)

(uf) 4.4.2.1 Amperage 159, 2.59, 3.6i amps

LIX 4.4.2.2 Voltage 1-2 4E3, 2-348.3, 1-3 48.3

$4 \mathbb{1} 4.4 .2 .3$ Frequency $61 . Z_{\mathrm{Hz}}$

Cle 4.4.2.4 011 Pressure 75 psi

C 4.4.2.5 Water Temperature $170^{\circ} \mathrm{F}$

4.4.3 Step 3 (100KW Resistive Load for $15 \mathrm{~min}$.)

lifk 4.4.3.1 Amperage 1 120, 2120,3120 amps

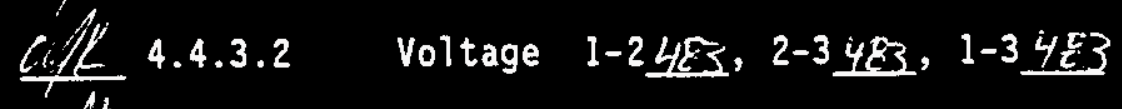

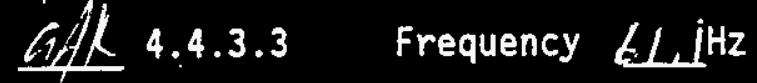

C.JK 4.4.3.4 0il Pressure 65 psi

a. 4.4.3.5 Water Temperature $175^{\circ} \mathrm{F}$

4.4.4 Verify voltage and clockwise phase rotation as noted for the following:

GQX 4.4.4.1 UTILITY 480 VAC 110 AMPS outlet

4.4.4.1.1 Phase rotation CLS

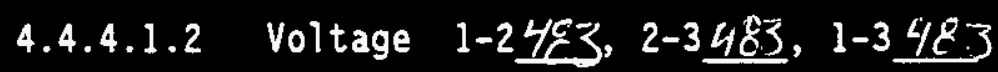


SIA 4.4.4.2 SERVICE TRAILER 240 VAC 80 AMPS outlet

\subsection{Voltage $1-2.240$}

CAP 4.4.4.3 BREATHING AIR COMPRESSOR 480 VAC 50 AMPS outlet

4.4.4.3.1 Phase rotation $C_{i L}$

4.4.4.3.2 Voltage $1-2483,2-3 \underline{483}, 1-3 \underline{4 \& 3}$

4. 4.4.4.4 240 VAC 20 Amp Single Receptacle

4.4.4.4.1 Voltage $24 i$ )

CAK 4.4.4.5 120 VAC 20 Amp Duplex Receptacle

\subsection{Voltage 20}

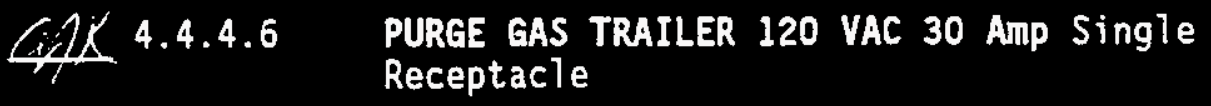

\subsection{Voltage 120}

4.4.5 Switch Run-0ff-Auto switch to Off.

4.5 No load hot start: Verify that the engine starts and comes to $1800 \mathrm{rpm}$ in the specified time. (MFR $\left.C-\mu C^{\circ} \mathrm{sec}.\right)$

AfK 4.5.1 Switch Run-0ff-Auto switch to Run. Time a sec.

4.5.2 Switch Run-off-Auto switch to off.

4.6 Loaded hot start: Verify, with the $100 \mathrm{KW}$ load bank on 1 ine, that the engine starts, comes to $1800 \pm 9 \mathrm{rpm}$, and the load is automatically switched on-line in the specified time. (MFR $C-\angle$ sec.)

C/X 4.6.1 Switch Run-0ff-Auto switch to Run.

(Time from close of contacts to load on-1ine. 2 sec.)

4.6.2 Switch Run-0ff-Auto switch off. 


\section{TEST EXCEPTIOHS}

\section{Step * Description of exception and resolution.}

$3,8,2$ Grounding 0.0 Goneratur Freme shuold be bunded

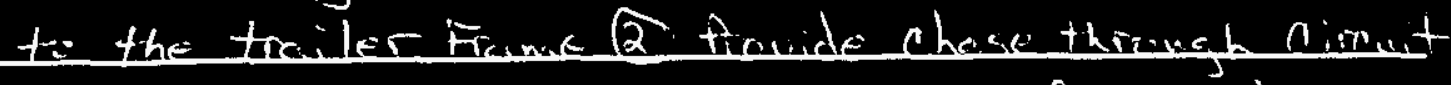

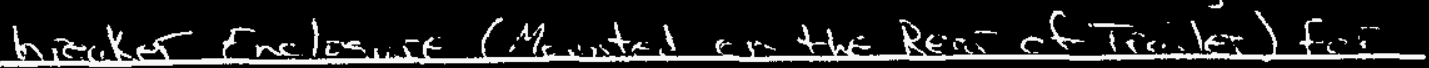

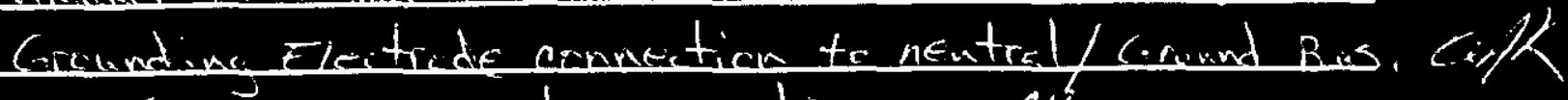
lierify upon receipt inspeation CARK

3.2 .2 Frequency for full load factory set 6. Ci Hz. Tust data showa lesiance which is expla mad by las

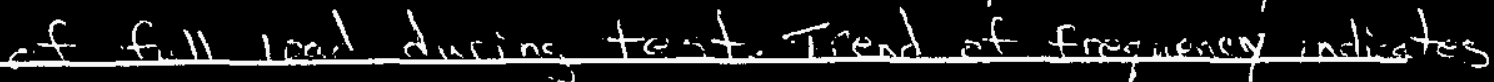
sanipmont is acpable G/K

TEST COMPLETED BY:

\begin{tabular}{|c|c|c|}
\hline PRINT NAME & SIGNATURE & DATE \\
\hline Alris I Kustelrik & 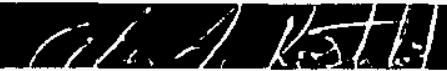 & $9-26.94$ \\
\hline CUAMINS NORIHLES 7 In' & (hatic2) 2alt & $9-26-94$ \\
\hline
\end{tabular}

Make additional copies as required. 
(87) Westinghouse Hanford Company Help. Stamp Out Suspects/Counterfeits

\section{Suspect Fastener Headmark List}

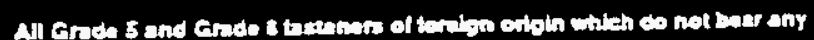

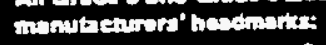

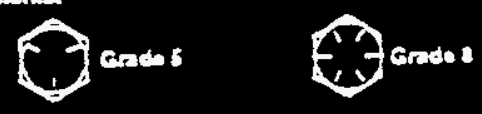

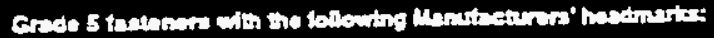

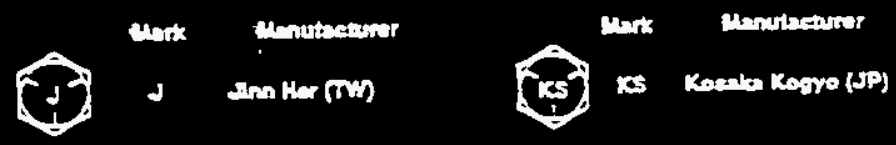

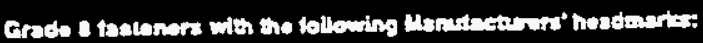

Matk Mnowacteres Matk Monutacturer

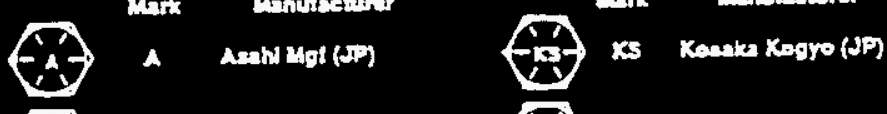

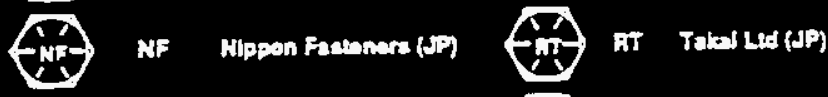

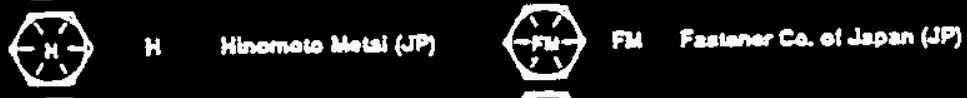

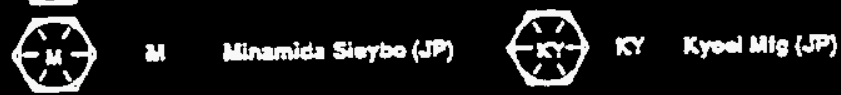

(-is) us uinato Kooro (j)

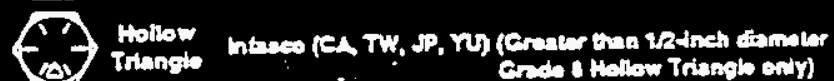

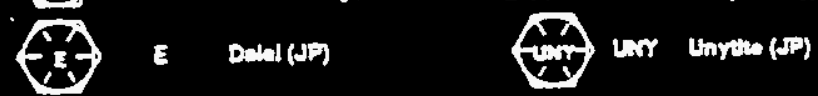

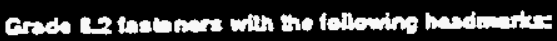

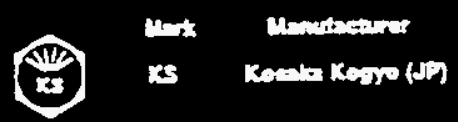

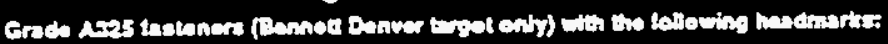

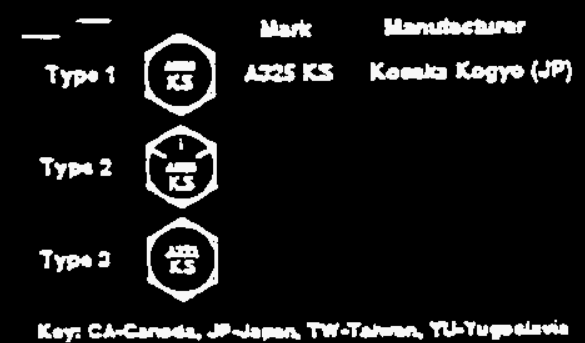

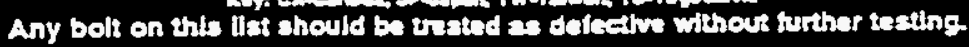


Ctnisitunit ui itu

Model 150DGFA 68913H

Customer CUMMINS NORTHWEST INC

SERVICE

RATING

FUEL TYPE

GOVERNOR TYPE

COOLING

SYSTEM

ITEMS
CHECKED/
ADJUSTED

\begin{tabular}{|l|l}
\hline X Prime & KW 135 \\
\hline Standby & KW \\
\hline
\end{tabular}

\section{S/N E940542240}

Order File Number U432913D P.0. 1311R

\section{Order File Nuher U432913\% P.0. 1311R}


$--R \quad U N N$ I N G

$\begin{array}{ccc}\text { KW } & \text { KVA } & \text { PF } \\ ---- & ---\end{array}$

135

1.00
$-----M$

A X----S U R G E--At Specified Voltage-.-

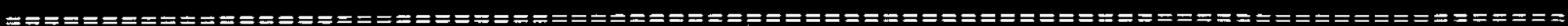

Recommended Genset Model: 150DGFA

Nominal KW Duty Specified Voltage

- - - - - - - -

- - -

Standby

150

$277 / 480$ WYE
KW Occurs in step

135

1
KVA

135
Occurs in step

1

Genset Voltage: 208-240/416-480

When operated at 500 Feet Altitude and 77 degrees Fahrenheit Ambient the operating performance is:

* Genset selected with one Genset. *

$\begin{array}{cccl}\text { Maximum } & \text { Voltage } & \text { Freq. } & \text { Excitation } \\ \text { KW } & \text { Dip } & \text { Dip } & \\ -150 & 19 \% & -1 \% & \text { Shunt }\end{array}$

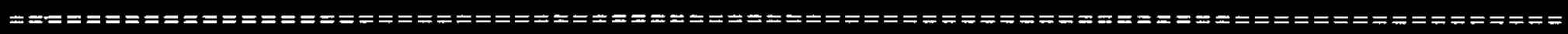

Onan Corporation has developed this Gensize 2 computer program to help you, the engineer, with a generator set selection. The recommendations are based upon your input of the genset requirements and typical performance data published by NEMA and other agencies.

Due to changing load and site conditions beyond our control, we cannot be certain the selection of a genset based upon the recommendation of this computer program will meet the site requirements. Therefore, nothing in this program may be construed as a warranty. You must decide for yourself or consult with your local Cummins/onan distributor that the generator set selected is sufficient for your intended purpose. Each Onan generator set is covered by an express written warranty which is in lieu of all other warranties, expressed or implied.

Please consult with your Cummins/Onan distributor representative in your area for further information. 
and engine/alternator capacity.

$135 \mathrm{KVA}$

2. Running load requirements and alternator capacity at site conditions.

3. Max load surge KVA and Max set KVA capacity with minimum $90 \%$ sustained voltage.

4. Max load Surge $\mathrm{KW}$ and Max set Surge KW capacity at site conditions with minimum $90 \%$ sustained voltage.

5. Transient Voltage Dip:

Allowable Transient Voltage Dip:

6. Total non-linear plus linear load $\mathrm{KW}$ and Alternator $\mathrm{KW}$ capacity.
$135 \mathrm{KW}$

19
35

$135 \mathrm{KW}$
187 Acceptable

150 Acceptable 187 Acceptable

563 Acceptable

189 Acceptable

Acceptable

150 Acceptable 
Project Name: (WESTINGHOUSE HANFORD)

Project Parameters:

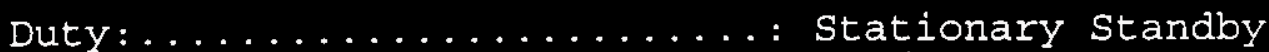

Voltage:.............. $277 / 480$ WYE

Frequency................ : 60

Max. Temp. Rise........... 105

Max. VDIP\%.............. 35

Max. Altitude............. 500

Altitude Scale............ Feet

Max. Amb. Temp............. 77

Temperature Scale.......... Fahrenheit

Cooling System............ Radiator

Fuel Type............... Diesel

Load Listing

Load Number: 1 Load Type: Resistive

Phase 3

Load Name: (135 KW PRIME) Input KW: 135

Comment :

SKW: SKVA: SKVAR: SPF : RKW: RKVA: RKVAR: RPF :

$\begin{array}{rrrrrrrr}135.0 & 135.0 & 0 & 1.00 & 135.0 & 135.0 & 0 & 1.00\end{array}$

Step Sequence/Load

Step Number: 1 Surge KW: 135 Surge SKVA: 135

Step Name: START $135 \mathrm{KW}$ PRIME LOAD

Comment :

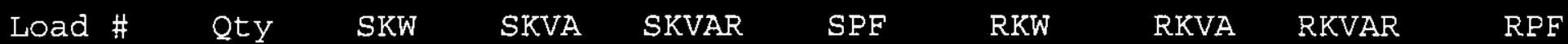

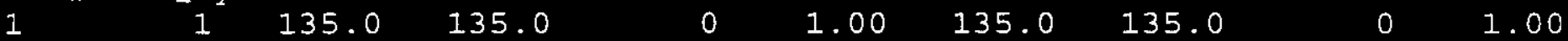

Step Total:
$135.0 \quad 135.0$
$0 \quad 1.00$
135.0
135.0
01.00

Cumulative:

$135.0 \quad 135.0$

$135.0 \quad 135.0$

0

Criteria Selection Results: Mode 1: 150DGFA

1. Running load requirements

Required

by Loads

- - - - - - -

$135 \mathrm{KW}$
Available

from Model Result

-.-.-.-.-.

150 Acceptable 
2. To: (Receiving Organization) Core Sampling

5. Proj./Pros./Dept./Div.:
3. From: coriginating Organization) Characterization Equipment 6. cos. Engr.:

Core Sampling Aux. Equipment J.L. Smalley

4. Retated EDT NO.:

$N / A$

8. Originator Renarks:

ETN-94-0023-D

This Acceptance Test Procedure is transmitted for approval.

The procedure was prepared by the Seller and will be performed at the Sellers location. It will show compliance with specification HHC-S-0252 Rev re.l a/K 4-7-74

11. Reseiver Renarks:

(12)

12. Major Assm. Dug. No.:

$N / A$

13. Permit/Permit Application No.: $N / A$

14. Required Response Date: $9 / 15 / 94$

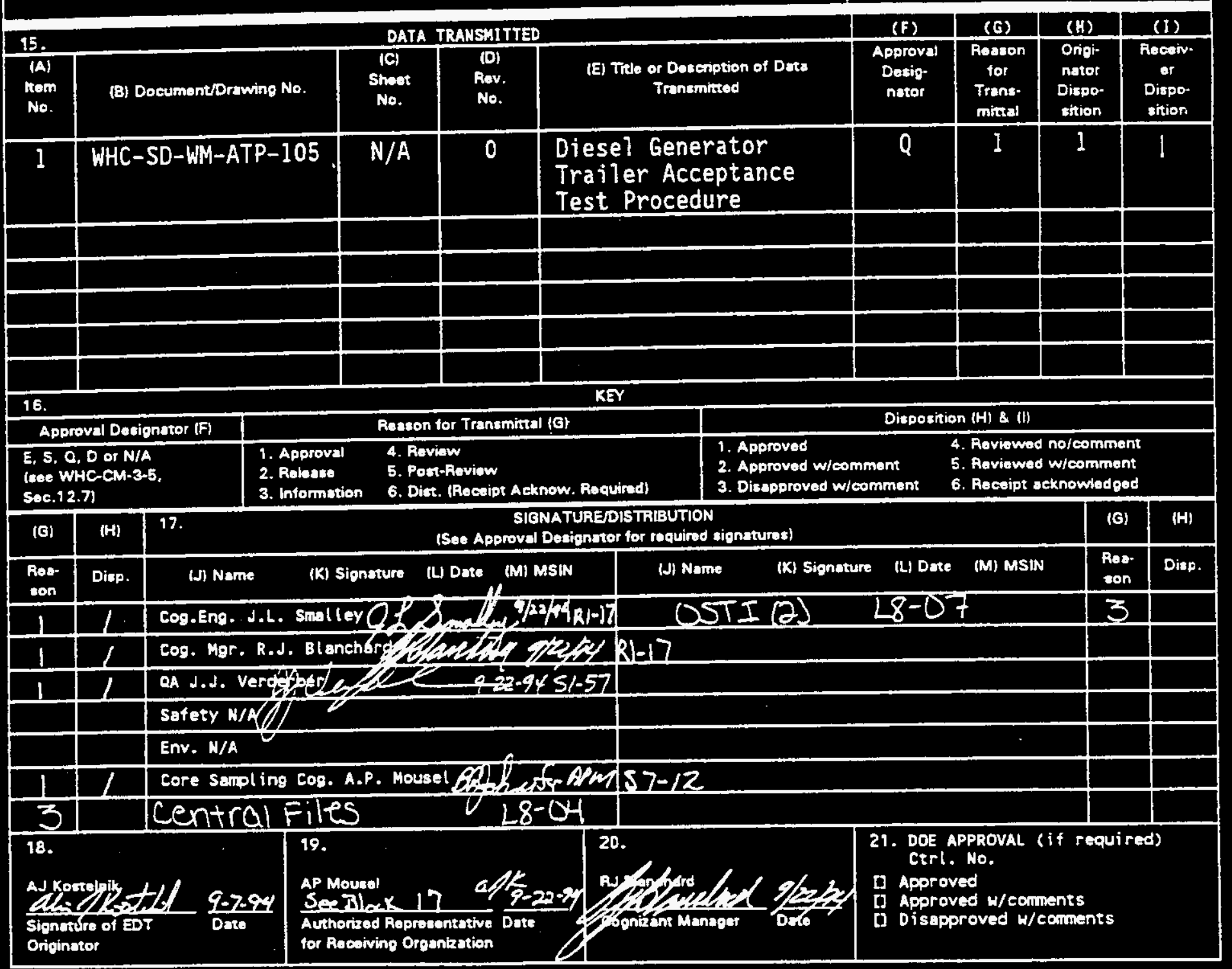

BO-7400-172-2(04/94) GEF097 


\section{RELEASE AUTHORIZATION}

Document Number: WHC-SD-WM-ATP-105, REV 0

Document Title: Diesel Generator Trailer Acceptance Test Procedure

Release Date: $\quad 9 / 23 / 94$

This document was reviewed following the procedures described in WHC-CM-3-4 and is:

APPROVED FOR PUBLIC RELEASE

WHC Information Release Administration Specialist:

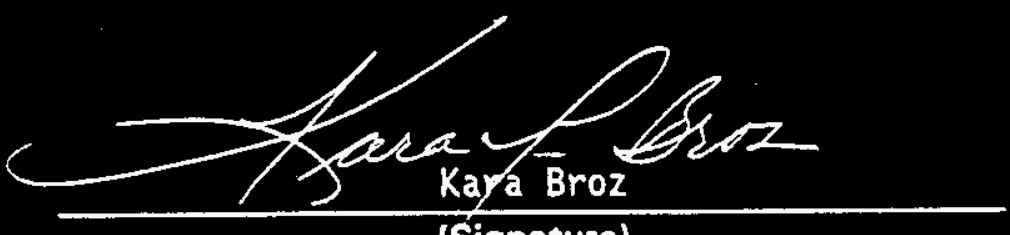

(Signature)

$\frac{9 / 23 / 94}{\text { (Date) }}$


2. Title

3. Nember

Diesel Generator Trailer Acceptance Test Procedure

MHC-SD-NM-ATP-105

4. Rev No.

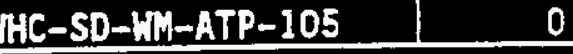

5. Key Hords

ETN-94-0023-D

Core Sampling, Diesel Generator, Specification

WHC-S-0252, Trailer, Cummins, Onan, 150KW

Generator, Purchase Order 404886, Core Sampting Auxiliary Equipment / LAPROVEO FOF $=\operatorname{ron}$

\section{Abstract}

\section{PUBLIO RELEASE}

6. Author

Mane: Alois J Kostelnik

This Acceptance Test Procedure (ATP) will document compliance with the requirements of WHC-S-0252 Rev.1 and ECNs 609271, and 609272. The equipment being tested is a 150KW Diesel Generator mounted on a trailer with switchgear. The unit was purchased as a Design and Fabrication procurement activity. The ATP was written by the Seller and will be performed by the Seller with representatives of the Westinghouse Hanford Company witnessing the test at the Seller's location.

8. POngose AND USE OF DOCMNENT - This document was prepared for use ith in U.S. Department of Energy and its contractope? It is to be used onkx to perform, direct, or integente work under U.S. Department of Energy contracts. This doodient is not approved for public release until reviewed.

PATERT STATUS - This doeumenp Foy, since it is transmitted in advance of patent clearagor, is made akajlable in confidence solely for use in perfourince of work undex contracts with the U.S. Department Energy. This document is notee be publ ished nor its conteats otherwise disseminated or used for purposes other than specifted above before patent approval for such release omuse has specittcd above before patent, from the Patent Counset, U.S. Department of Energy field office, Richland, HA.

DISCLAINER - This report was prepared as an account of work sponsored by an agency of the United States Goverment. Neither the United States coverment nor any agency thereof, nor any of their eniployes, nor any of their contractors, subeontractors or their employees, makes any warranty, express or implied, or assumes any

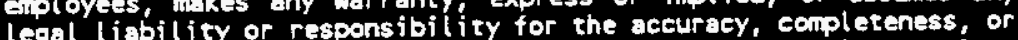
any third party's use of the results of such use of any information, apparatus, product, or process disclosed, or represents that its use apparatus, product, or prot infringe privetely owned rights. Reference herein to any specific comercial product, process, or service by trade name, tradenark, manufacturer, or otherwise, does not necessarily constitute or imply its endorsement, recommendation, or favoring by the United states Governuent or any agency thereof or its contractors or subcontractors. The views and opinions of authors expressed herein do not necessarily state or reflect those of the United States Government or any agency thereof.

10. RELEASE STAMP

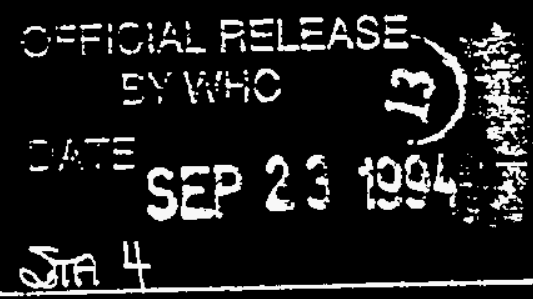


WHC-SD-WM-ATR-105

Rev. 0

Appendix B-4 of B-19

TABLE OF CONTENTS

1.0 scope . . . . . . . . . . . . . . . . . . . . . 3

2.0 Test Performance . . . . . . . . . . . . . . . . . 3

3.0 Inspection Plan ...................... 3

4.0 Run Test .......................... . 8

TEST EXCEPTIONS . . . . . . . . . . . . . . . . . . . . 12

SUSPECT FASTENER HEADMARK LIST . . . . . . . . . . . . . . . . 13 


\subsection{Scope}

This acceptance test procedure is to verify that the trailer mounted 150KW Cummins/Onan Diesel Generator Set meets the requirements of Westinghouse Hanford specification WHC-S-0252.

\subsection{Test Performance}

Cummins Northwest will complete the following test in the order deemed best by Cummins personne?. West inghouse Hanford Company (WHC) personne? shall witness all testing and shal1 perform the inspection portion of the test. Al] steps will be completed and any exceptions shall be noted on the attached exception sheet along with the resolution. Cummins Northwest shall resolve all exceptions with the concurrence of WHC.

\subsection{Inspection Plan}

3.1 Record the model and serial numbers of the Generator Set and Trailer.

\begin{tabular}{|c|c|}
\hline GENERATOR SET & TRAILER \\
\hline $1150 D G F A$ GEVI3H & $V_{1} V^{\prime}-1094 \mathrm{~S} 1923 \mathrm{RS}$ \\
\hline $3 d^{\prime}=940547197$ & $15 i 338$ \\
\hline
\end{tabular}

3.2 Verify by record review that the generator is capable of the following:

\& 3.2.1 3-phase, 4-wire, 277/480 VAC and single-phase 240/120 VAC.

C. 3.2 .2 Operating frequency is $60 \mathrm{Hertz} \pm 0.5 \%$. Sece exception

Q 3 K 3.2 .3 Standby Rating Range is 150KW 0.8 power factor.

G. 3.2 .4 Prime Rating Range is $135 \mathrm{KW}$ * 0.8 power factor.

C.AK 3.2 .5 Voltage dip does not exceed $20 \%$ of rated voltage upon application of rated load at rated power factor. Fei Gansize 2 pirturt

L/K 3.2 .6 voltage regulation under load from no 10 ad to $100 \% 10$ ad is within $\pm 2 \%$ of rated voltage, $( \pm 10 \mathrm{~V})$.

lif 3.2 .7 Frequency regulation under varying loads from no load to $100 \%$ load is within $\pm 3 \mathrm{~Hz}$. 
3.3 Verify the control panel contains the following:

(R) 3.3.1 Run-Off-Auto switch: (Run: manually start engine) (Off: stop engine) (Auto: start engine by closing of a remote contact) R.m step Remote:

3.3.2 Accessible remote start-stop terminals.

3.4 Verify controls are provided to shutdown and lock out the engine under the following abnomal operating conditions:

3.4.1 Engine failure to start after a specified cranking time.

3.4.2 Engine over-speed.

3.4.3 Engine low lube oil pressure.

3.4.4 Engine high operating temperature.

3.4.5 Remote manual stop activated.

3.5 Verify the following instrumentation is provided as a minimum:

Lif 3.5.1 Engine lube oil pressure gauge.

(I) 3.5 .2 coolant temperature gauge.

ifl

3.5.3 Hour meter.

IA 3.5 .4 Battery volt meter.

ifK 3.5 .5 Fuel gauge for day tank.

$\frac{\text { (i.) }}{\text { (1.K) }}$

3.5.6 Cranking time meter (Internal timer, alarm light indicator) 3.4 .1

3.5.7 Other instruments normally provided by the manufacturer for Duplicute: the proper operation and maintenance of their enginegenerator set. the lligh Engine To.nperature fre lick $c_{1}$ l fiesinit

3.6 Verify battery-powered visual and audibie alarms for the following condition as a minimum are provided. Verify alarm test switch, lamp test switch and alarm reset switch and contacts for each alarm for remote signaling are provided:

3.6.1 Over-crank shutdown.

GK 3.6.2 High engine temperature shutdown.

3.6.3 Low engine lube oil pressure shutdown.

3.6.4 Over-speed of engine shutdown. 
3.7 Verify the generator AC power output monitoring and controls include the following as a minimum:

3.7.1 AC voltmeter with a phase selector switch with an OFF position.

3.7.2 AC anmeter with a phase selector switch with an OFf position.

3.7.3 Frequency meter.

3.7.4 AC voltage adjust rheostat.

3.7.5 Generator output circuit breaker with manual reset.

3.8 Verify the following equipment has been installed:

3.8.1 The basic trailer is Rers

3.8.1 The basic trailer is provided with an electrical equipment rack located on the side-of the engine-generator set enclosure that does not increase the total width dimension of the unit. The equipment rack is located for easy access but allows accessibility to the engine-generator set for maintenance and operation. All receptacles are on the same side of the generator and labels are mechanicaliy fastened to the equipment with screws.

3.8.2 The distribution and wiring system have been installed per NFPA 70, National Electrical Code. see: Excintion

3.8.3 There is a 25KVA transformer on the unit to provide single phase power of 240/120 volt. The transformer has fault protection on the primary side.

3.8.4 A 100KW load bank is on the unit. The load bank is divided into 3 sections, 2 (two) 25KW and 1 (one) 50KW sections, which may be manualiy switched on individually as required to maintain the generator near $70 \%$ of capacity. The $10 a d$ bank is wired for operation in parallel with the normal load. 
3.8.5 The electrical equipment furnished by the engine-generator set Supplier, mounted on the equipment rack outside of the engine-generator set enclosure, and wired to the generator output terminals via a 3-phase, 4-wire bus is as follows: (Rated current capacity of components shail not be less than the rating requested.)

One (1), 3-pole, 3-wire, 150 amp rated, 80 amp trip, 600 VAC, lockable circuit breaker. A 100 amp. receptacle is on the load side of the circuit breaker and is labeled as "SERVICE TRAILER 240 VAC 80 AMPS". The receptacle is an Appleton Cat. \# ADR1034.

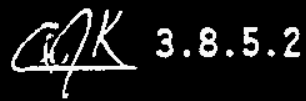

One (1), 3-pole, 3-wire, 150 amp rated, 50 amp trip, 600 VAC, time delay lockable circuit breaker. A 60 amp. receptacle is on load side of the circuit breaker and is labeled as "BREATHING AIR COMPRESSOR 480 VAC 50 AMPS". The receptacle is an Appleton Cat. \# ADR6034.

One (1), 3-pole, 3-wire, 200 amp rated, 110 amp trip, 600 VAC, lockable circuit breaker. A 200 amp. receptacle to the load side of the circuit breaker and label receptacle as "UTILITY 480 VAC 110 AMPS". The receptacle is an Appleton

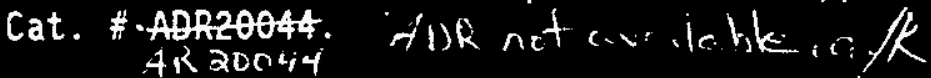
G.8. 3.8 One (1), 20 amp, 240 VAC, single receptacle, wired from a two pole, 20 amp breaker to be used for hookup of temporary power boxes. Labeled as "240 VAC 20 ANPS".

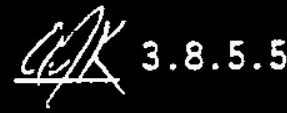

One (1), $20 \mathrm{amp}, 120 \mathrm{VAC}$, duplex receptacle, wired from a single pole, 20 amp breaker with ground fault protection, to be used for hookup of temporary tools and lighting. Labeled as "120 VAC 20 AMPS".

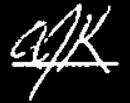

3.8 .5 .6

One (1), 30 amp, $120 \mathrm{VAC}$, single receptacle, wired from a single pole, 30 amp breaker. Labeled as "PURGE GAS TRAILER 120 VAC 30 AMPS".

3.8.6 The unit has grounding rods and a 100 foot cable to allow grounding to a ground grid. $T_{c}$ be lecified at recesipt

$$
\begin{aligned}
& \text { Inspection. cigf } \\
& \text { * } 4 \text { atper minimum a/k }
\end{aligned}
$$


3.9 Verify the following engine-generator trailer requirements are satisfied:

Alk

3.9.1 The engine-generator set including all accessories are mounted on a heavy duty type trailer designed for use in construction, communications, and utility applications.

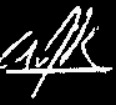

3.9.2 The trailer meets Department of Transportation (DOT) requirements for highway travel. (DOT Certification)

Cak

3.9.3 Vibration isolators are used between the engine-generator set and the Eenerator frawe.

(1)

3.9.4 The trailer is equipped with running lights, brake lights, safety brake, stabilizer jack on each corner; a front wheel jack with whee1; and hitches.

(1)

3.9.5 The trailer has a $23 / 4$ inch Lunette hitch with vertical adjustment.

lalk

3.9.6 The underside of the trailer is undercoated for rust protection.

(1)

3.9.7 The trailer has hydraulic surge type brakes.

3.9.8 The generator is within an enclosure and the enclosure is lined with sound deadening material.

3.9.9 The instruments and controls are vibration isolated to prevent gauge and control malfunction. 
3.10 Verify the following engine requirements are satisfied:

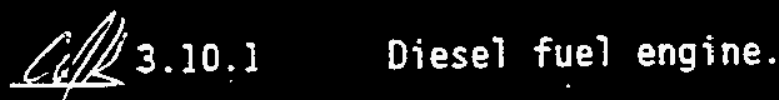

Go/K 3.10 .2

LIX 3.10 .3

CAIS 3.10 .4

(fi) 3.10 .5

(1) 3.10 .6

SAK 3.10 .7

CIC 3.10 .8

1fK 3.10 .9

1.) 3.10 .10

cik
Engine shall be electric start from negative grounded battery supplied.

Battery shall be charged with alternator having automatic voltage regulation supplied with engine.

A fuel tank is on the unit that will supply fuel for the engine to operate at full load for at least 24 hours. (Capacity 25C gal, Consumption rate $2 \mathrm{Z}$ gal/hr)

Two (2) stage dry type air cleaner with a restriction gauge.

Furnished with the capability for cold weather starting such as electric glow plugs. Engine hot start 1500 watt, 110 volt heater.

Record the freeze point of the engine antifreeze. $\left(-4 C^{\circ} \mathrm{F}\right)$

Drip pan to catch fuel or oil leaks.

Painted inside and out. Exterior is White.

Verify there are no Suspect Fasteners as identified on the U.S. Custom's Fasteners Headmark List.

Verify all visible welds are acceptable per AWS D1.I.

\subsection{Run Test}

4.1 No Load Cold start: Verify that the engine starts and comes to $1800 \pm 9 \mathrm{rpm}$ in the specified time. (MFR $C^{*}-12 \mathrm{sec}$.)

4.1.1 Switch Run-0ff-Auto switch to Run.

(Time from close of contacts to $1800 \mathrm{rpm} 2 \mathrm{sec}$. )

4.1.2 Verify the following instrumentation is functional and the value indicated is within the range specified by the manufacturer:

E.II 4.1 .2 .1 (1) 4.1 .2 .2
Engine lube oil pressure gauge.

$$
\text { ( } 25 \text { psi, MFR in-in psi) }
$$

Coolant temperature gauge. 
all 4.1.2.3 Hour meter.

(l.h.hens)

clall

4.1.2.4 Battery volt meter.

(25 volts, MFR int - volts)

G.1L $4 \cdot 1 \cdot 2.5$

Fuet gauge for day tank.

$1 / 44.1 \cdot 2 \cdot 6$

(Emity level)

Other instruments normally provided by the manufacturer for the proper operation and maintenance of their particular engine-generator set.

c) 4.1 .3 Record and with a sound meter the generator noise level at the electrical control panel and yerify that it is less than

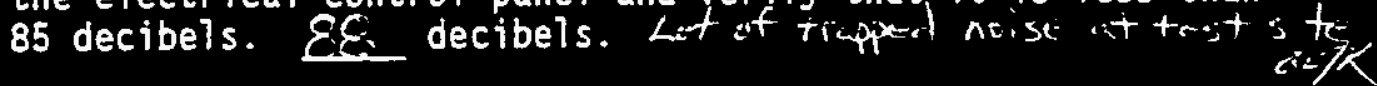

4.2 Loaded Coid start with Remote/Auto start: Verify, with the $100 \mathrm{KW}$ load bank on line, that the engine starts, comes to $1800 \pm 9 \mathrm{rpm}$, and the load is automatically switched on-line in the specified time. (MFR $C_{i}-1 C_{\text {sec. }}$ )
Rernute

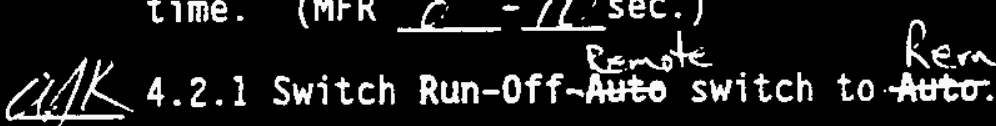

4.2.2 Close contacts on a temporarily installed switch.

(Time from close of contacts to foad on- the. Remote Full spered sec.)

4.2.3 Switch Run-0ff-Atto switch to off. (Remove temporary switch.)

4.3 Verify controls shutdown and lock out the engine under the following simulated abnormal operating conditions. (Temporarily install contacts and jumpers as required to simulate conditions. Restart the generator between each alarm test.) Verify alarm test switch, lamp test switch and alarm reset switch are operational:

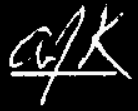

4.3.1 Engine failure to start after a specified cranking time, with atarn. - Baycles lk: on lkeff, light

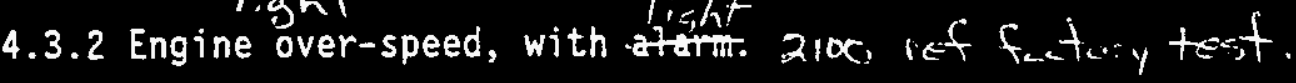

4.3.3 Engine low lube oil pressure, with fight Phe Linc.l Piescire

4.3.4 Engine high operating temperature, with fight $\&$ fre High Engme Temp.

cif/

4.3.5 Remote manual stop activated. Hocated-on-distribution. panot Tempoiaiy switch. 
4.4 Verify proper operation of the generator, power distribution components and load bank according to the manufacturer's supplied information. (For load bank test operate for 15 minutes at each step prior to recording information.)

4.4.1 Step 1 (25KW Resistive Load for 15 min.) 30

lifl 4.4.1.1 Amperage 13Q, 30,30 tet 3 amps

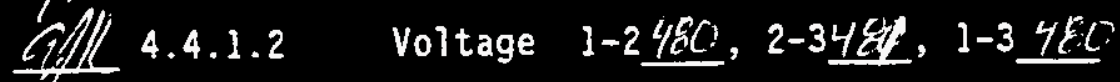

iff 4.4 .1 .3 Frequency $2.5 \mathrm{~Hz}$

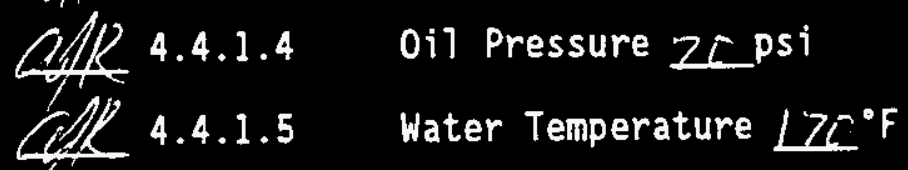

4.4.2 Step 2 (50KW Resistive Load for 15 min.)

CAP 4.4.2.1 Amperage $1 \angle C, 2 \notin C, 3 \notin C$ amps

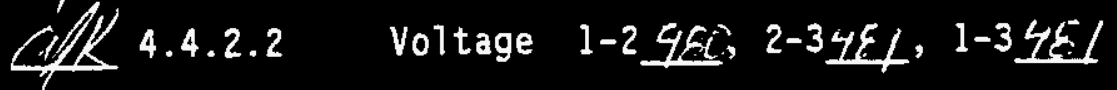

AfK 4.4.2.3 Frequency $6.2 .15 \mathrm{~Hz}$

Q1/ 4.4.2.4 0ii Pressure $\geq \mathcal{C}$ psi

11/ 4.4.2.5 Water Temperature $170^{\circ} \mathrm{F}$

4.4.3 Step 3 (100KW Resistive Load for $15 \mathrm{~min}$.)

(1) A.4.3.1 Amperage $1419,2119,3 \not 19$ amps

lek 4.4.3.2 voltage $1-248 \mathrm{c}, 2-3481,1-34 E C$

Q. 4.4 .3 .3 Frequency $6.1 .4 \mathrm{~Hz}$

(1) 4.4.3.4 0il Pressure Zi.psi

$4 / K$ 4.4.3.5 Water Temperature $17 \mathrm{C}^{\circ} \mathrm{F}$

4.4.4 Verify voltage and clockwise phase rotation as noted for the following:

GPK 4.4.4.1 UTILITY 480 VAC 110 AMPS outlet
4.4.4.1.1 Phase rotation C.L.?

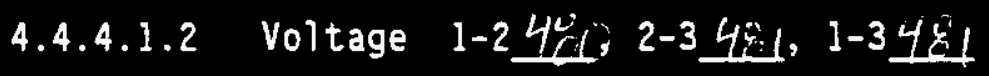


Q 4 4.4.4.2 SERVICE TRAILER 240 VAC 80 AMPS out let

\subsection{Voltage $1-2239$}

(14)

4.4.4.3 BREATHING AIR COMPRESSOR 480 VAC 50 AMPS outlet

4.4.4.3.1 Phase rotation $\mathrm{Cl}_{\text {L }}$

4.4.4.3.2 Voltage $1-2 \underline{481}, 2-3 \underline{481}, 1-3 \underline{4 \varepsilon 1}$

ing

4.4.4.4 240 VAC 20 Amp Single Receptacie

4.4.4.4.1 Voltage 239

GM

4.4.4.5 120 VAC 20 Amp Duplex Receptacie

4.4.4.5.1 Voltage 120

s.

4.4.4.6 PURGE GAS TRAILER 120 VAC 30 Amp Single Receptacie

4.4.4.6.1 Voltage 120

4.4.5 Switch Run-0ff-Auto switch to Off.

4.5 No load hot start: Verify that the engine starts and comes to $1800 \mathrm{rpm}$ in the specified time. (MFR $5-1 \tau \mathrm{sec}$.)

C 4.5.1 Switch Run-0ff-Auto switch to Run. Time $2 \mathrm{sec}$.

ill 4.5.2 Switch Run-0ff-Aute switch to off.

4.6 Loaded hot start: Verify, with the $100 \mathrm{KW}$ load bank on 1 ine, that the engine starts, comes to $1800 \pm 9 \mathrm{rpm}$, and the load is automatically switched on-line in the specified time.

(MFR $c^{-}-1 i^{-} \mathrm{sec}$.)

LYK 4.6.1 Switch Run-0ff-A sute switch to Run.

(Time from close of contacts to raad-on-line. 2 sec.)

lifk 4.6.2 Switch Run-0ff-Autto switch off. 


\section{TEST EXCEPTIONS}

\section{Step \# Description of exception and resolution.}

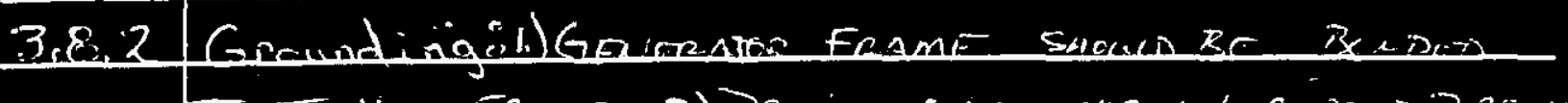

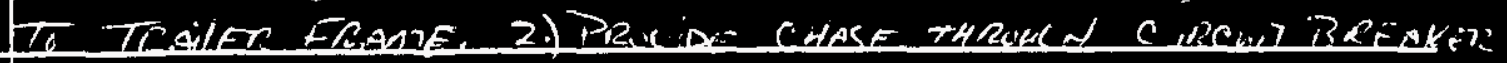

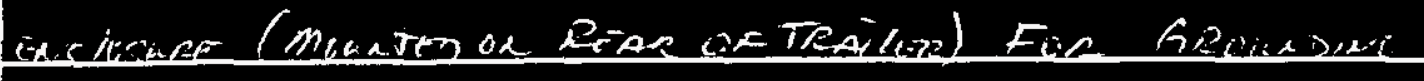

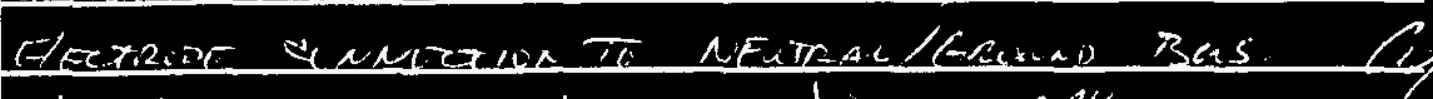

ilerify upan reacipt inspectic $\Omega$, lelk

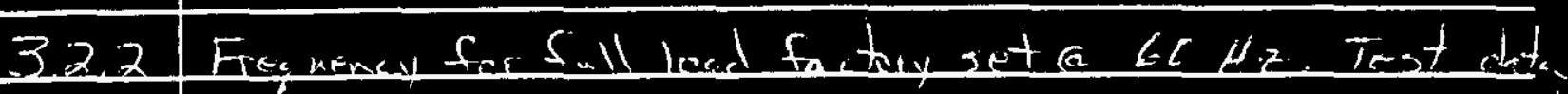

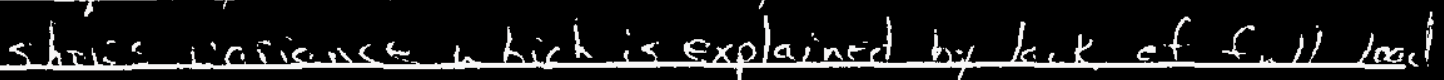

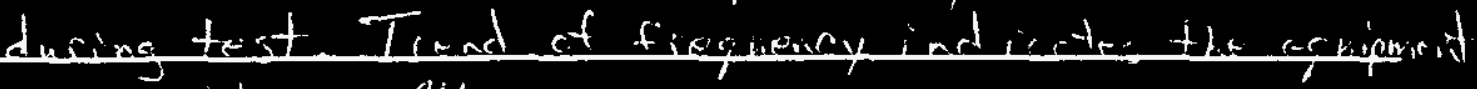
is rajable. G JK

TEST COMPLETED BY:

$-$

\begin{tabular}{|c|c|c|}
\hline PRINT NAME & SIGNATURE & DATE \\
\hline Ale is J Kostelnik & Calis) thatid & $4-2 t-94$ \\
\hline 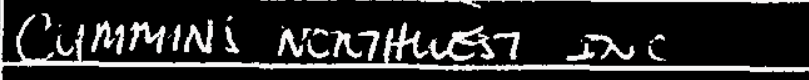 & Qbilat. & $9-26-94$ \\
\hline
\end{tabular}


(8) Westinghouse Hanford Company Help.Stamp Out Suspects/Counterfeits

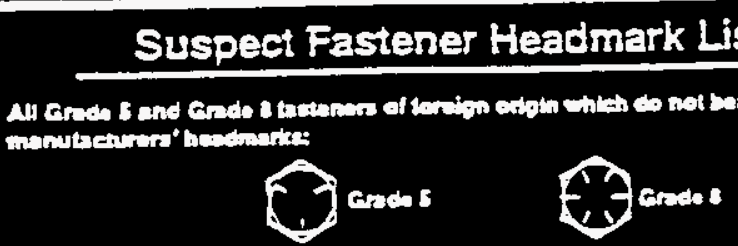

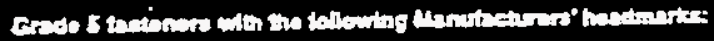

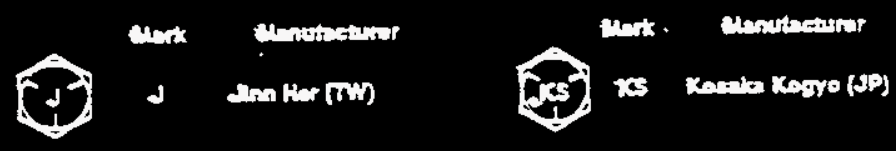

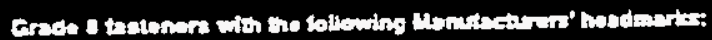

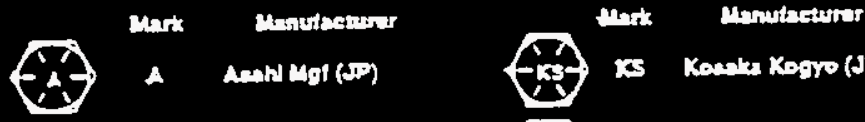

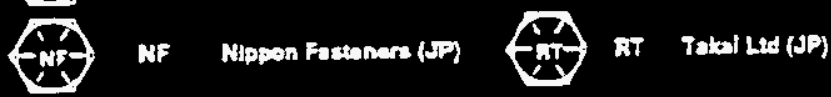

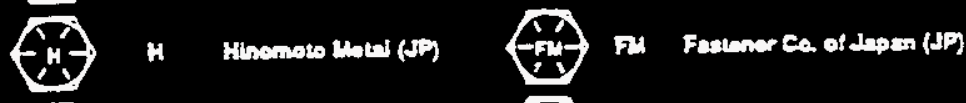

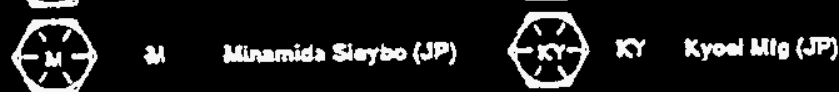

(us as unato kearo (JP)

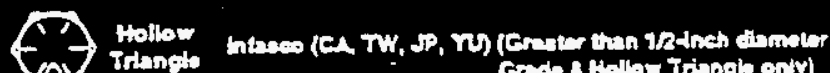

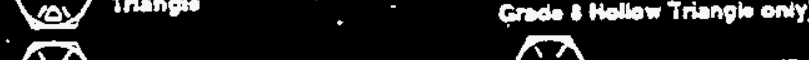

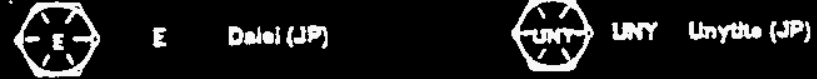

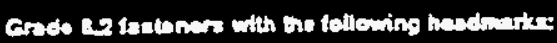

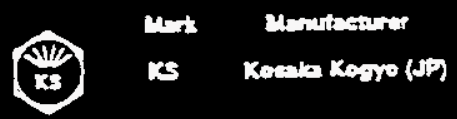

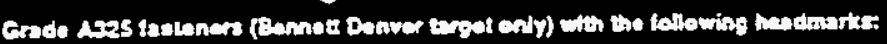

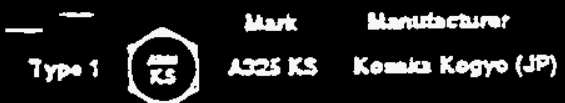

$$
\begin{aligned}
& \text { Trou } 2 \text { (1) }
\end{aligned}
$$

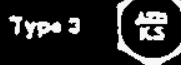

Any bolt on this ifst should be treated as detecthe without hurther teating. 
Model 150DGFA 68913H

Customer CUMMINS NORTHNEST INC

SERVICE

RATING

FUEL TYPE

GOVERNOR TYPE

COOLING

SYSTEM

ITEMS
CHECKED/
ADJUSTED
S/N F940547197

Order File Number U434358D/P.0. 11353R

\begin{tabular}{l|l|l|l}
$X$ Prime & KW 135 & KVA & 169 \\
\hline Standby & KW & KVA & \\
\hline
\end{tabular}

Gasoline $X$ Diesel _ LP Vapor

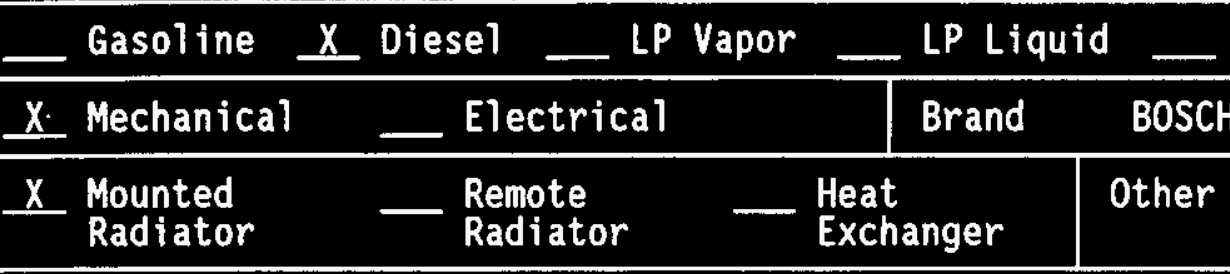

Nat Gas

Other

$\underline{X}$ Governor $\underline{X}$ Remote Start

$\mathrm{X}$ Voltage Regulator

$\underline{X} 0 i 1$ Pressure Pre-Alarm $\underline{X} 0 i 1$ Pressure Shutdown $\underline{X}$ Meter Accuracy

$\underline{X}$ Hi Cool Temp Pre-Alarm $\underline{X}$ Hi Cool Temp Shutdown _ LET Alarm

$\underline{X}$ Overspeed 2100 RPM $X$ Overcrank Sec 16 Crank 16 Rest 13 Total

$X$ Other: List: B255 F001 H462 H480 KH22 H389 K001

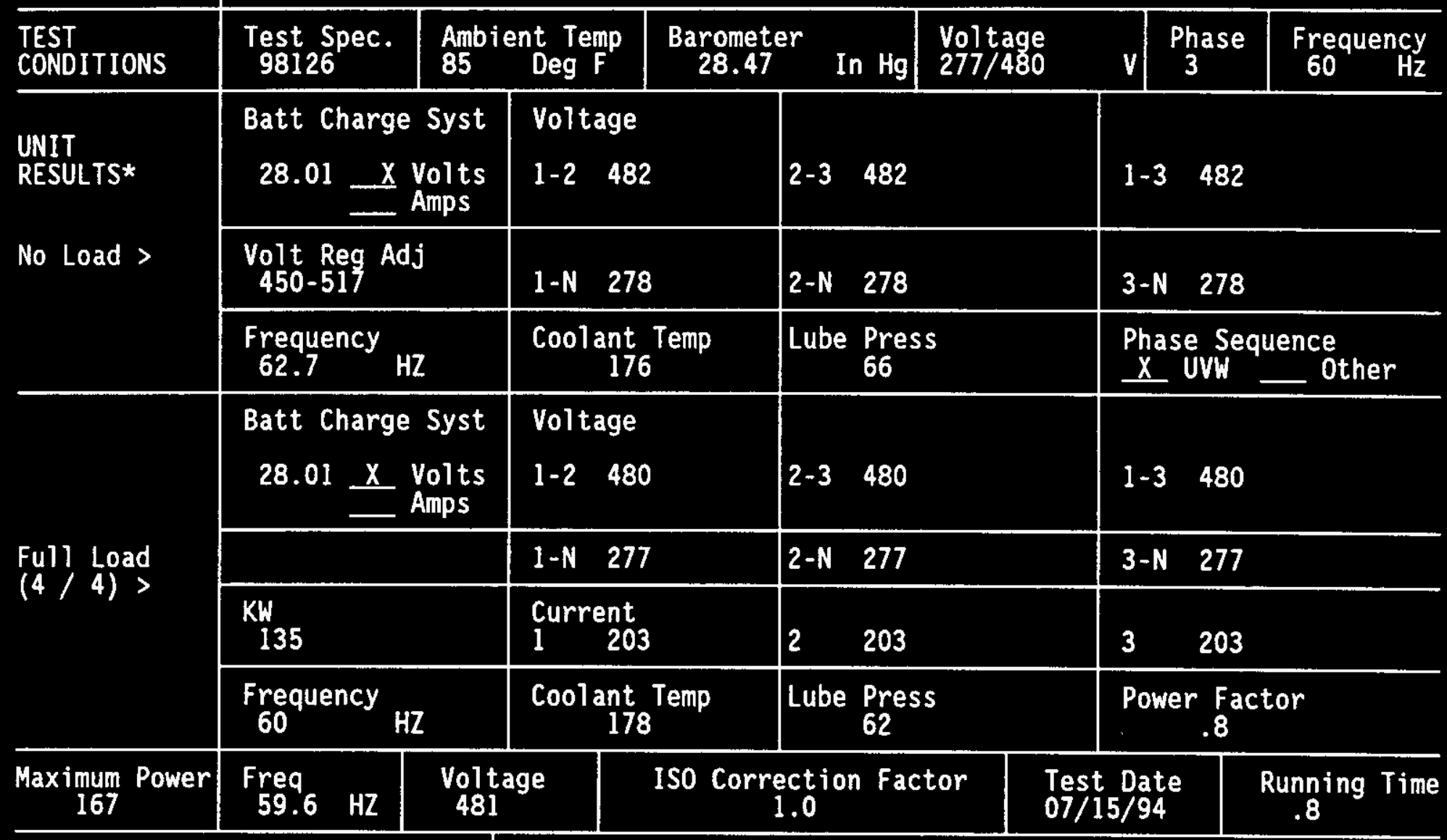

Data Recorded \& Certified By:

$R$ HOGEN 4139

Quality Engineer:

Date:

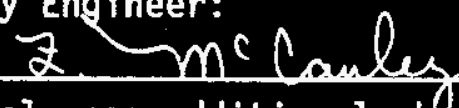

$7 / 21 / 94$

X22A041-Front $1 / 90$ * If unit is dual fuel, see additional sheet for second fuel results.

19-78

Mail to

$22105410 / 91$

(See reverse side for extended running time data.) vumuins Northulest, Ine.

Eli Su' Grady way

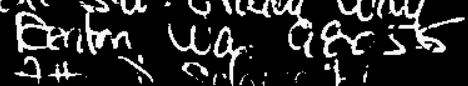

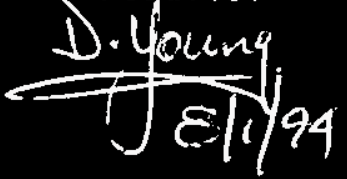




\begin{tabular}{cccccc} 
Nominal KW & Duty & Specified Voltage & Freq. & Specified Recommended \\
\hdashline 150 & Standby & $277 / 480$ WYE & 60 & 105 & 105
\end{tabular}

When operated at 500 Feet Altitude and 77 degrees Fahrenheit Ambient the operating performance is:

* Genset selected with one Genset. *

\begin{tabular}{cccl} 
Maximum & $\begin{array}{c}\text { Voltage } \\
\text { KW }\end{array}$ & $\begin{array}{c}\text { Freq. } \\
\text { Dip }\end{array}$ & Excitation \\
\hline 150 & $19 \%$ & $-1 \%$ & Shunt
\end{tabular}

Onan Corporation has developed this Gensize 2 computer program to help you, the engineer, with a generator set selection. The recommendations are based upon your input of the genset requirements and typical performance data published by NEMA and other agencies.

Due to changing load and site conditions beyond our control, we cannot be certain the selection of a genset based upon the recommendation of this computer program will meet the site requirements. Therefore, nothing in this program may be construed as a warranty. You must decide for yourself or consult with your local Cummins/onan distributor that the generator set selected is sufficient for your intended purpose. Each Onan generator. set is covered by an express written warranty which is in lieu of all other warranties, expressed or implied.

Please consult with your Cumins/Onan distributor representative in your area for further information. 
and engine/alternator capacity.

2. Running load requirements and alternator capacity at site conditions.

3. Max load surge KVA and Max set KVA capacity with minimum $90 \%$ sustained voltage.

4. Max load Surge $K W$ and Max set Surge

KW capacity at site conditions with

minimum $90 \%$ sustained voltage.

5. Transient Voltage Dip:

Allowable Transient Voltage Dip:

6. Total non-linear plus linear load

$\mathrm{KW}$ and Alternator $\mathrm{KW}$ capacity.
$135 \mathrm{KW}$

$135 \mathrm{KW}$

$135 \mathrm{KVA}$

$135 \mathrm{KVA}$

$135 \mathrm{KVA}$

$19 \%$

$35 \%$

$135 \mathrm{KW}$
187

150

187

563

189

Acceptable

Acceptable

150

Acceptable 
Project Name: (WESTINGHOUSE HANFORD)

Project Parameters:

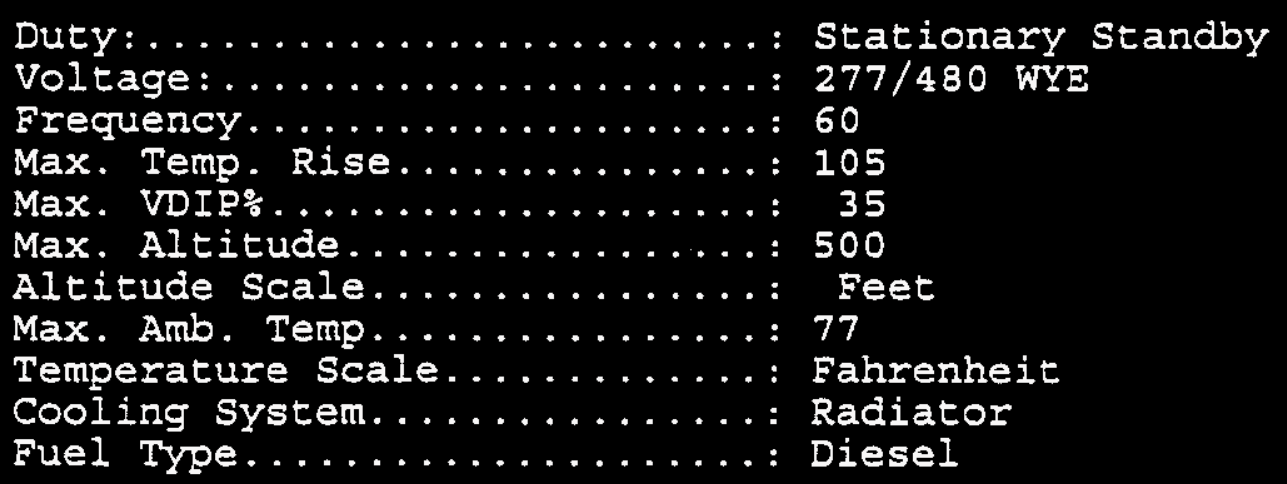

Load Iisting

umber: 1 Load Type: Resistive

Phase 3

ame: (135 KW RRIME) Input KW: 135

t:

KW : SKVA: SKVAR: SPF: RKW: RKVA: RKVAR: RPF :

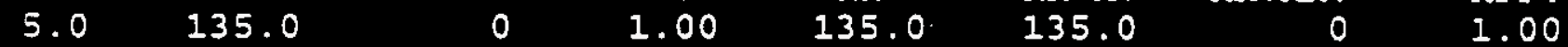

Step Sequence/Load

umber: I Surge KW: 135 Surge SKVA: 135

ame: START $135 \mathrm{KW}$ PRIME LOAD

t :

$\begin{array}{crrrlrrrr}\text { Qty } & \text { SKW } & \text { SKVA } & \text { SKVAR } & \text { SPF } & \text { RKW } & \text { RKVA } & \text { RKVAR } & \text { RPF } \\ 1 & 135.0 & 135.0 & 0 & 1.00 & 135.0 & 135.0 & 0 & 1.00\end{array}$

'otal:

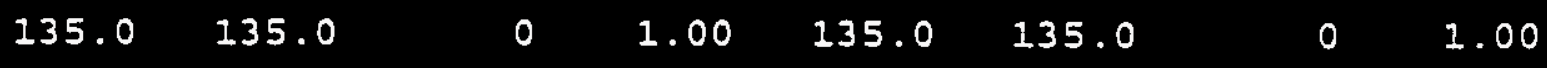

tive:

$135.0 \quad 135.0$

$135.0 \quad 135.0$

0

-ia Selection Results: ISODGFA

Required

by Loads

ining load requirements
- - - . - . - -

$135 \mathrm{KW}$
Available

from Model Result

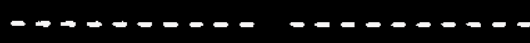

150 Acceptable 
From: Electrical Power Systems Engineering

Phone: $\quad 376-8109$ L4-90

Date: $\quad$ October 17,1994

Subject: CORE SAMPLING EQUIPMENT GENERATORS

To:

Al Kostelnik

RI-17

cc: CMM File/LB

Two Diesel generator sets by Cummins Diesel, 800 Grady Way, Renton Washington, $200 \mathrm{Kva}$ each. The generators are $480 \mathrm{Y} / 277$ volt units.

The generators are installed on trailers fabricated for the units. The trailers have an industrial control panel enclosure. The enclosure is a NEMA 4 outdoor rated enclosure. The control panel has a dead front through which the handles of all circuit breakers are accessible.

The circuit breakers are properly rated and installed. Wire sizes were examined and found to be correct.

Also on the trailer is a $25 \mathrm{Kva}$ transformer to supply $120 / 240$ volt single phase power. The neutral ground point is located in the industrial control pane1. A $100 \mathrm{KW}$ load bank is mounted on the front of the generator unit. The load bank can be switched to provide load in increments of $25 \mathrm{KW}$.

Items requiring further attention.

1. The only provision for connection of a grounding electrode is inside the generator enclosure. A mechanical set screw type lug is bolted to the generator frame.inside the louvered door on the right side of the unit. This location does not allow connection of the grounding electrode conductor and closing of the louvered doors.

2. The generator neutral is internally grounded to the generator frame, however the generator is mounted on rubber vibration isolation pads. The neutral ground point of the generator and the trailer mounted transformer must be the same point.

3. The procurement specifications require that two ground rods (size was not specified) and 100 feet of grounding electrode conductor be provided. The grounding electrode conductor and the ground rods were not provided with the two units observed.

4. The acceptance criteria called for rotation checks of the three phase power. All three phase circuit breakers and receptacles were checked and found to have consistent clockwise rotation. However, the rotation required by the actual three phase loads to be connected was not evaluated. 
A] Kostelnik

Appendix $\mathrm{C}-2$ of $\mathrm{C}-2$

Page 2

October 17,1994

Recommendations.

1. The neutral and equipment grounds are connected to a terminal bar located inside the industrial control enclosure. It is recommended that a chase be provided through the enclosure, below the level of all enclosed components, to allow the appropriate grounding electrode conductor to be routed from the grounding electrode selected to the neutral grounding bar inside the enclosure. This chase will allow the grounding electrode conductor to connect the grounding bar to the grounding electrode without splice or tap.

2. The generator housing is bonded to the generator frame with a braided bonding strap. A similar bonding strap should be provided to bond the generator frame to the trailer frame.

3. Include two $5 / 8 \times 10$ ground rods and 100 feet of \# 4 AWG copper wire for connection to a grounding electrode system. The required grounding electrode conductor for the ground rods is \#6 AWG.

4. A bump test for rotation check of all three phase motor loads will have to be accomplished at the time of first connection to the generator unit.

Conclusion. There were no NEC violations or safety issues not mentioned above that would prevent this unit from safely performing it's intended function.

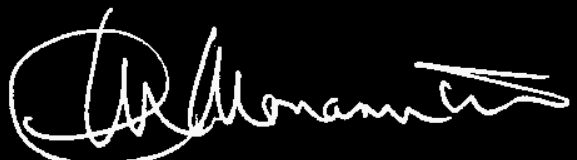

CM Monasmith, NEC Interptative Authority

Electrical Power Systems Engineering

rmg 


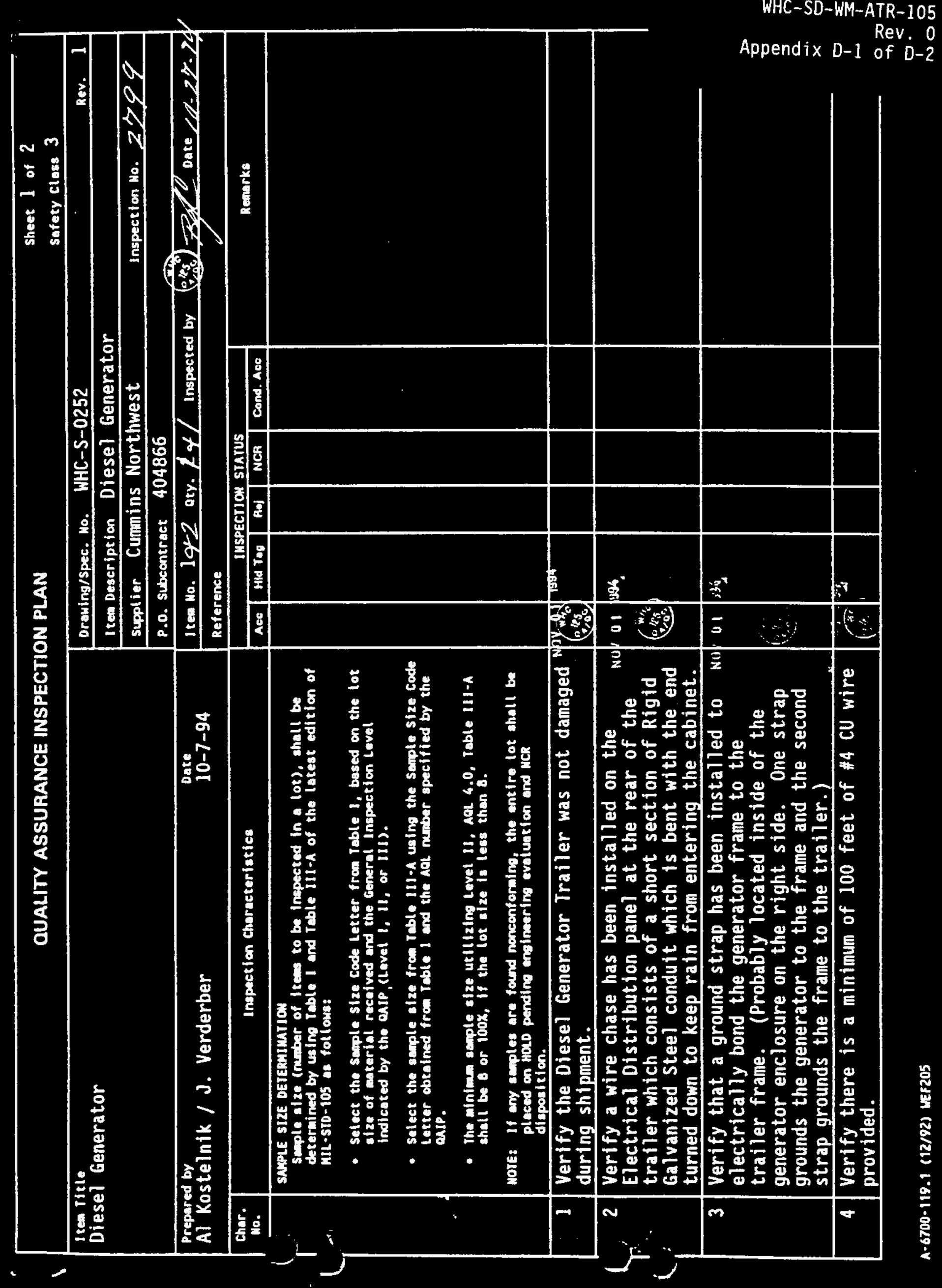




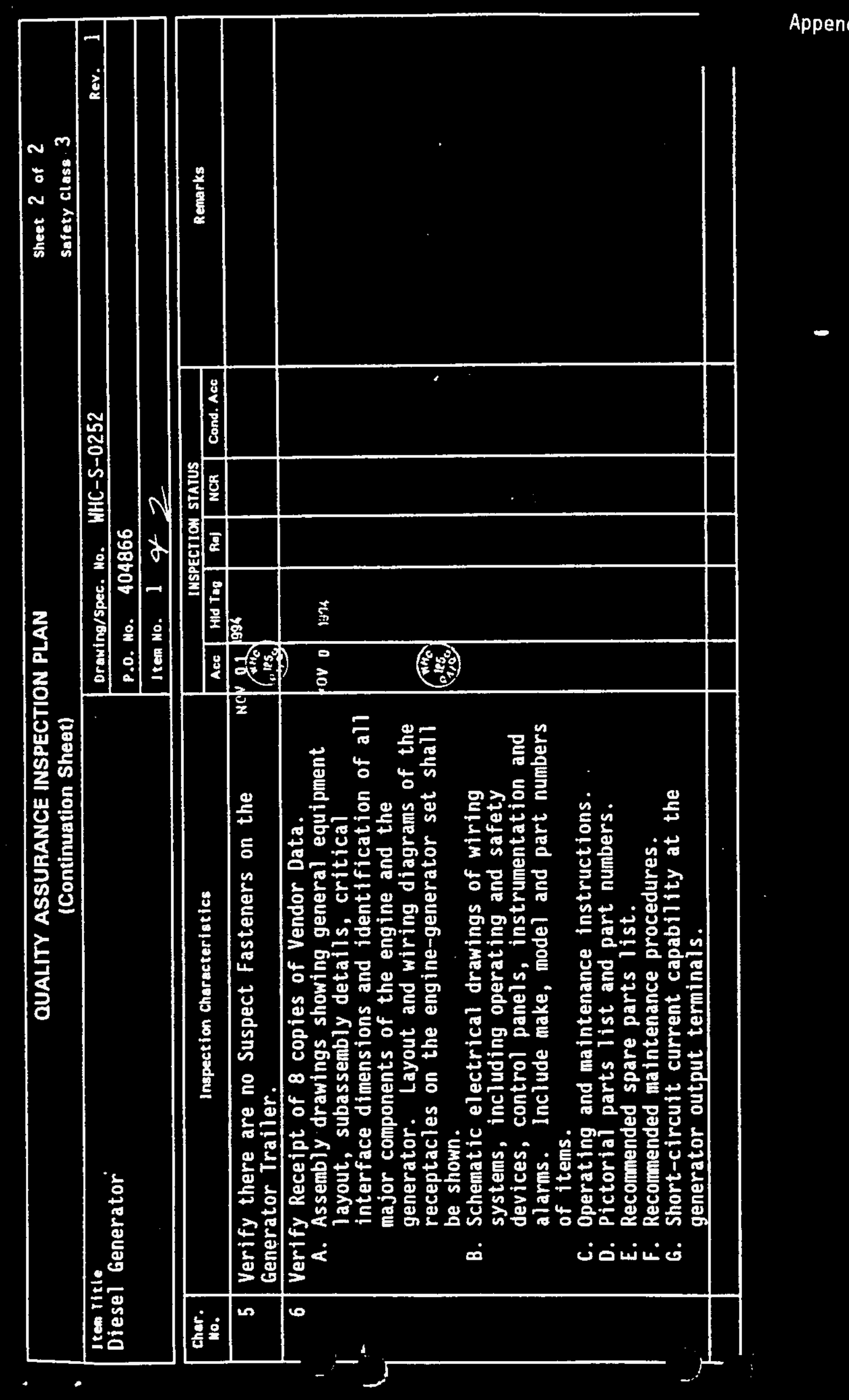

